\title{
دور الجامعات في تنمية القدرات الإبداعية لدى الطلبة
}

الاكتورة: بتلة صفوق العنزي

أستاذ الإدارة التزبوية المساعد كلية العلوم و الآداب

جامعة حفر الباطن - المملكة العربية السعودية

\section{ملخص الار اسة}

هدف البحث إلى تسلبط الضوء على مفهوم الإبداع الطلابي، و أهمية، والدور الحيوي

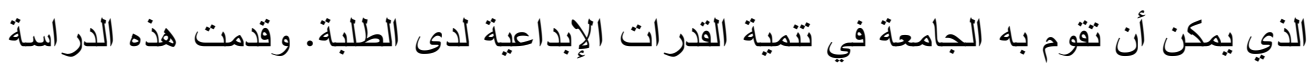

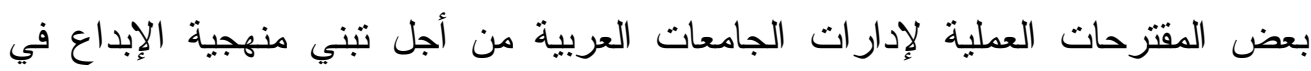

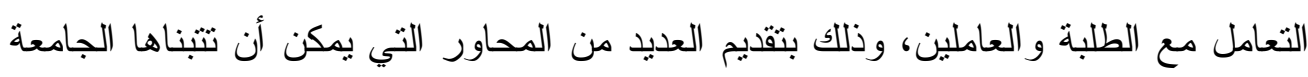

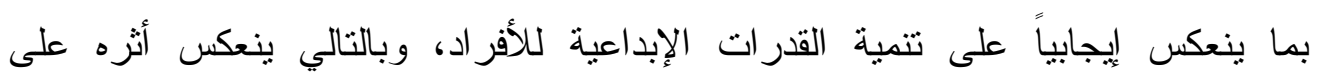
المجنمع.

وقد استخدم هذا البحث المنهجية المكتبية التحليلية عن طريق مسح النتاج العلمي المنشور (إلكترونيا أو ورقياً)، وجرى البحث عن ذللك في الإنترنت، وقو اعد البيانات

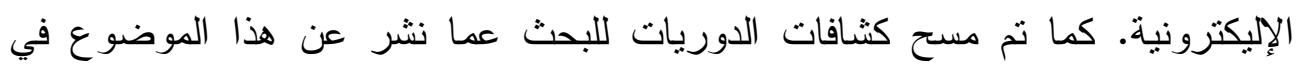

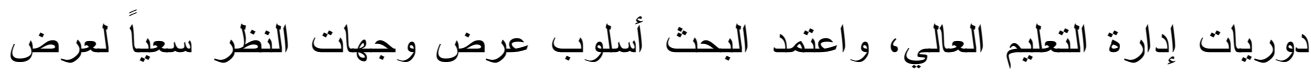
أكبر عدد ممكن من الأفكار و التصور ات الخاصة بهذا الموضوع ولئو وبما يمكن من بناء وجهة نظر حوله. وخلص البحث بتقديم عددًا من التوصيات و المقترحات 


\section{Abstract}

The study aimed to shed light on the concept of student creativity, and the importance of, and the vital role to be played by the university in the development of creativity among students. This study provided some practical proposals for the departments of Arab universities in order to adopt a creative methodology in dealing with students and staff, and by providing many of the themes that can be embraced by the university to positively affect the creative abilities of the members of the development, and thus reflected its impact on society.

This methodology analytical study office has been used by scanning scientific output prism (electronic or hardcopy), and there were discussions about it in the Internet, and electronic data bases. As it has been cleared headlamp patrols to search what is published about this topic in higher education management patrols and adopted a research presentation of views in order to offer the greatest possible number of ideas and perceptions on the subject and making it possible to build a point of view about it.

The study ended by providing a set of recommendations and proposals 
الجامعة مؤسسة متميزة للتعليم العالي تسهم في إعداد قادة المستقبل في مختلف

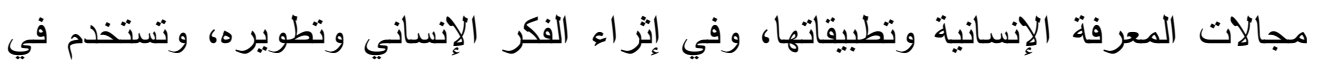

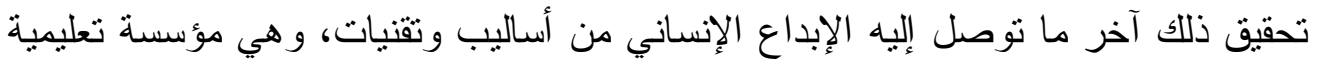

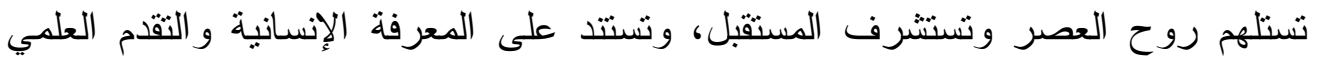

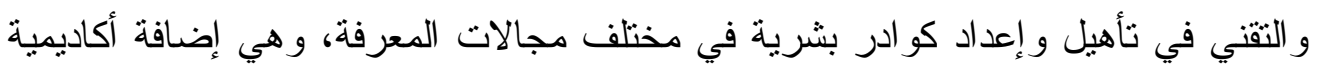

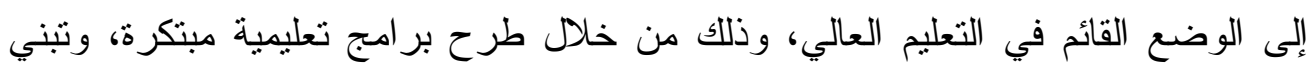
وسائل تعليمية حديثة بعيدة عن التقليدية. إنّ من أهم سمات التعليم الجامعي التي تميّزه عن عن مرحلتي التلئي التعليم الأساسي و الثانوي

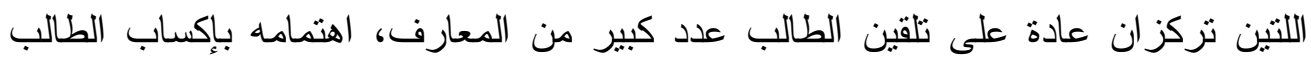

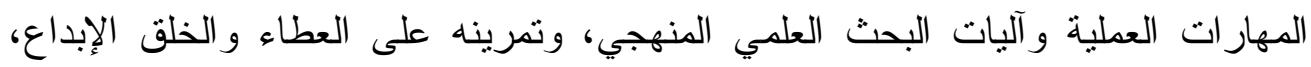

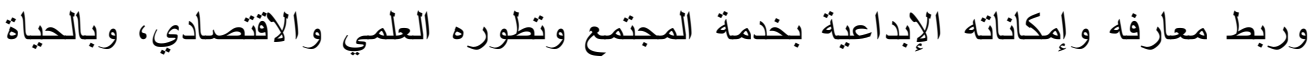

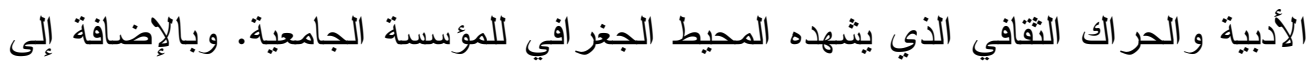

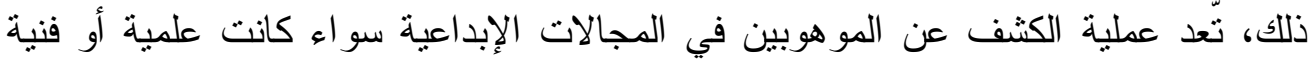

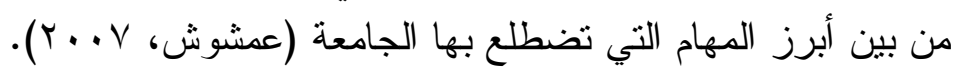

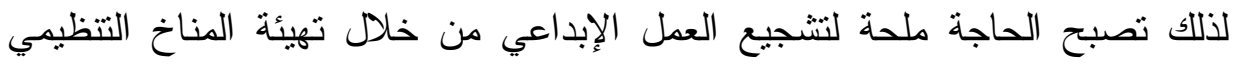

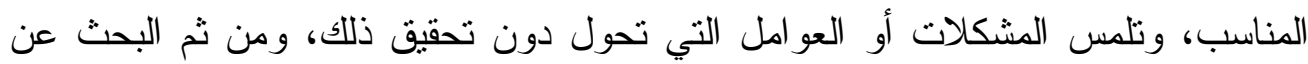

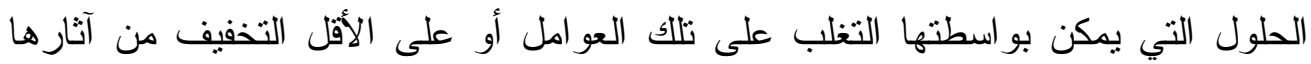

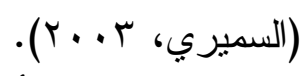

ومن المعلوم أنّ عدداً من الباحثين قد بدعوا بركزون على ضرورة تدريس المفاهيم

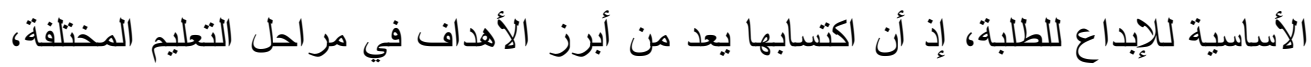

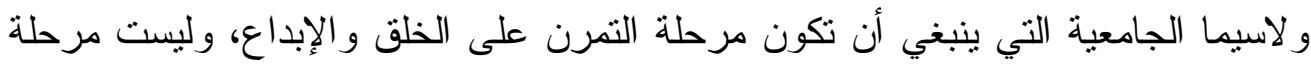

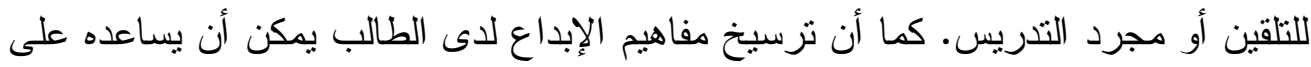

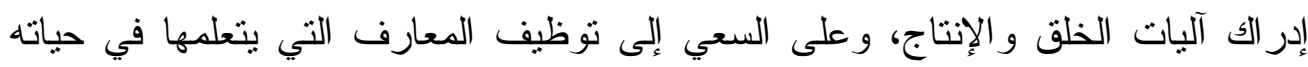

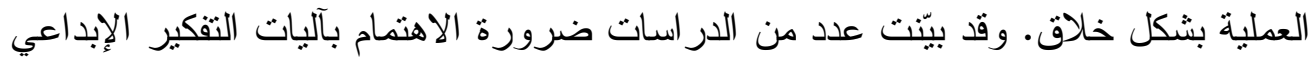

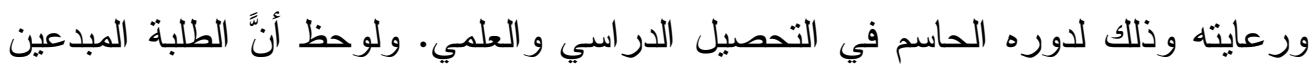

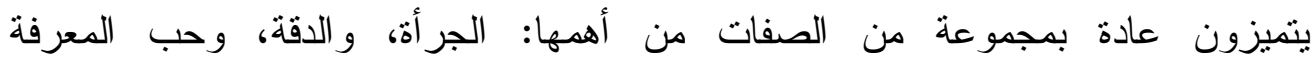

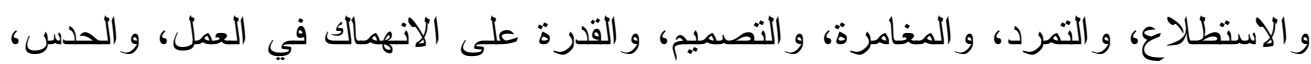

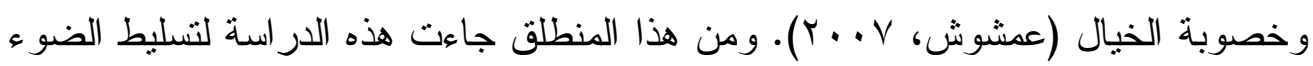

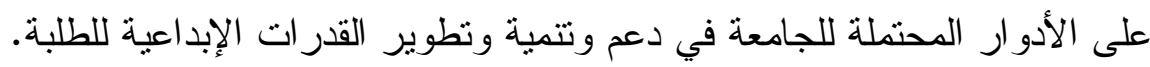




\section{مشكلة البحث:}

إن التحو لات التي شهدها العالم اليوم خصوصا بعد انبثاق عصر الثورة التكنولوجية

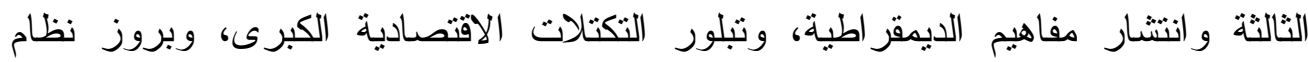

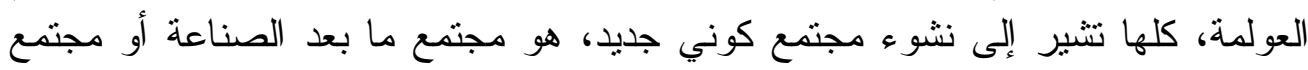

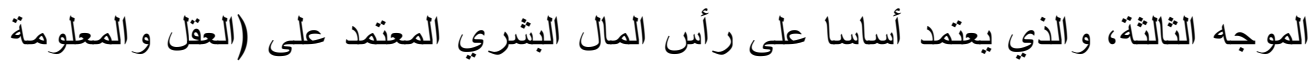

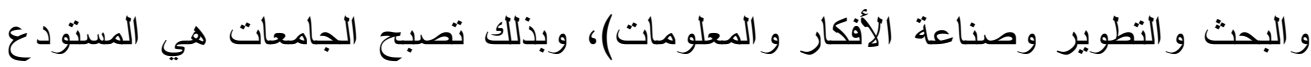

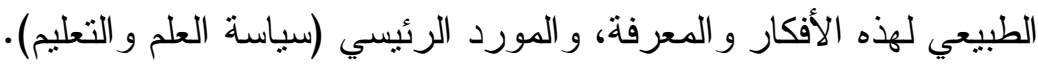

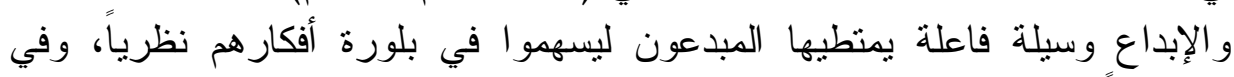

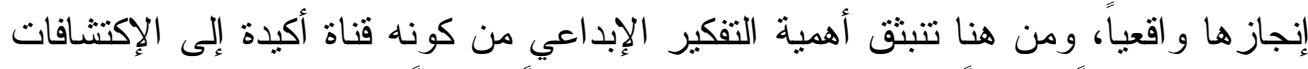

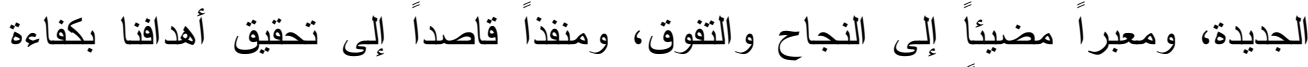

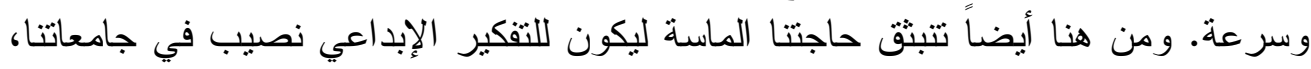

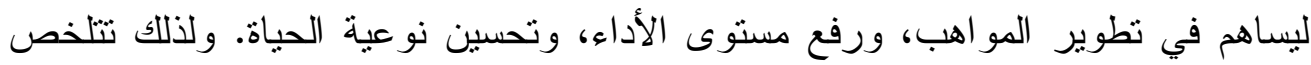

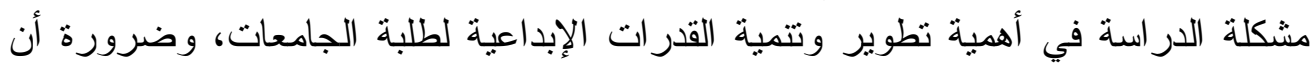

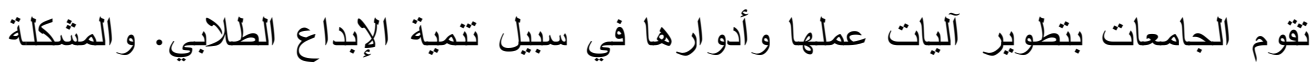

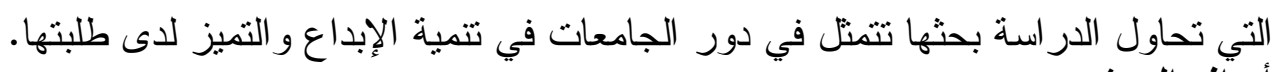
أهذأف البحث: يهدف البحث إلى تحقيق هدفين رئيسين هدف علمي وآخر عملي، وذللك على النحو النالي: - يهدف البحث على المستوى العلمي إلى إلقاء الضوء على دور إدارة الجامعات في تنمية

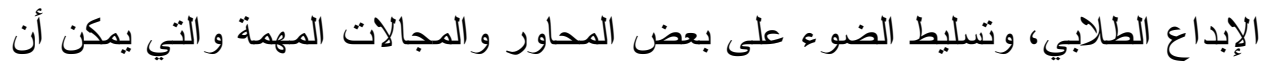

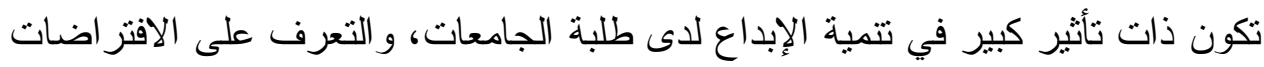

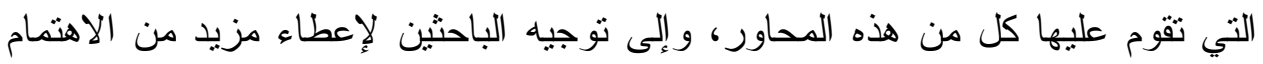

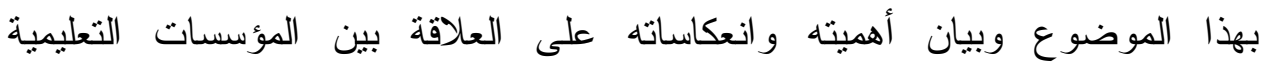

$$
\text { و المجتمعية. }
$$

- أما على المستوى العملي فيهدف البحث إلى لفت نظر أصحاب القرار في مؤسسات

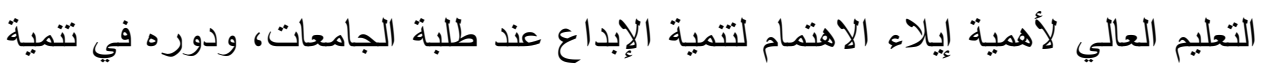

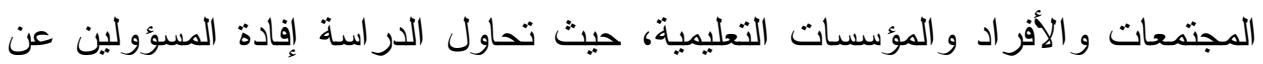

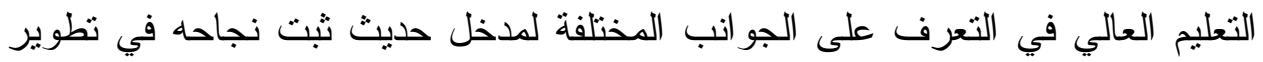

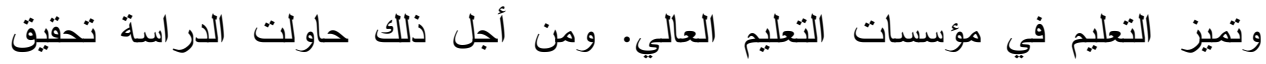
الأهداف الفرعية التالية: 
البحث الحالي دراسة مكتبية Library research تحليلية وصفية، وذلك لملاعمتها

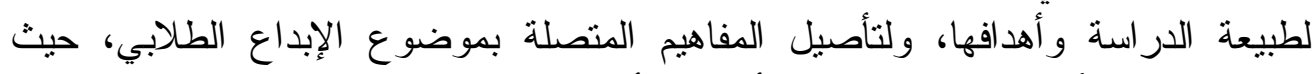

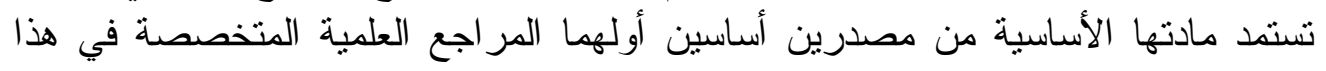

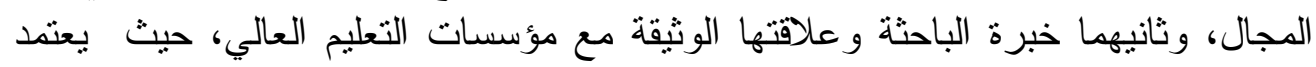

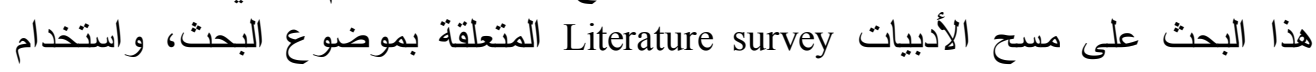

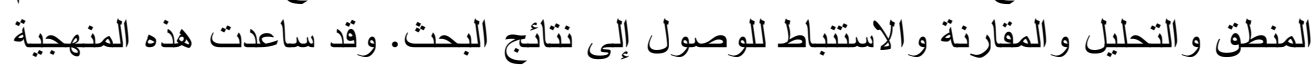

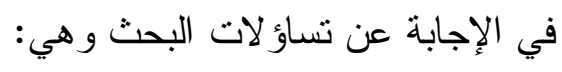

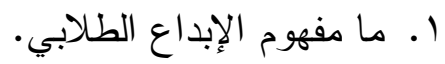

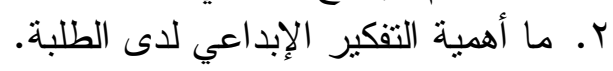
r. ما دور الجامعات في تتمية العملية الإبداعية عند الطلبة الطبة. الأدب النظري مفهوم الإبداع الطلابي. تعددت التعاريف التي تناولت مفهوم الإبداع، ويعزى ذللك الاختلاف إلى إلى اختلاف

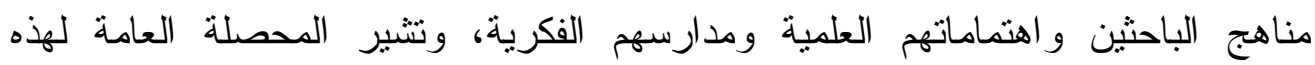

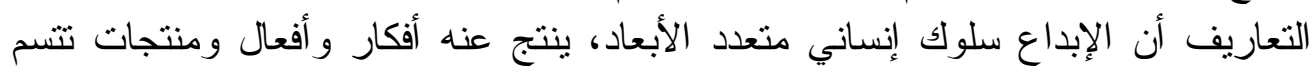

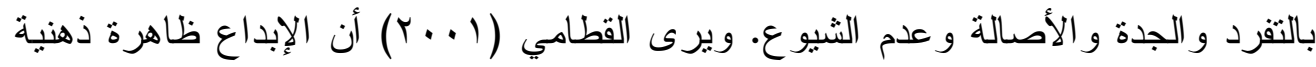

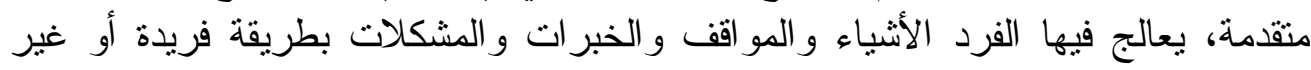

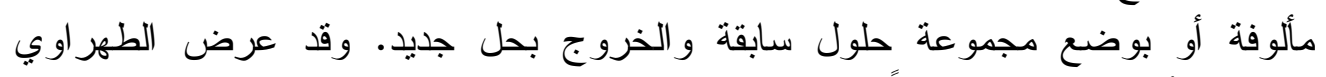

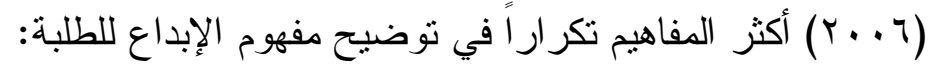
- الإتيان بالجديد. - الإتيان بالأمور غير المعروفة. - التفكير بطريقة غير تقليدية. - التفكير بنمط مختلف عن الآخرين. - التفكير التجديدي. - التعامل مع القضايا بطريقة غير معروفة التهة.

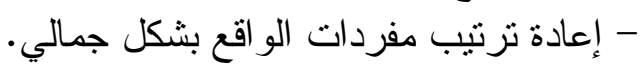

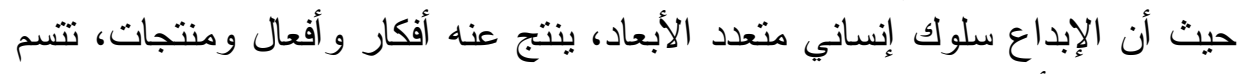

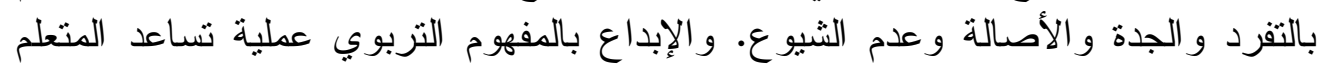


على أن يصبح أكثر حساسية للمشكلات وجوانب النقص و الثغر ات في المعلومات و اختلال الانسجام، وتحديد مو اطن الصعوبة، و البحث عن حلول وتكهن وصياغة فرضيات وانتان وانتبار

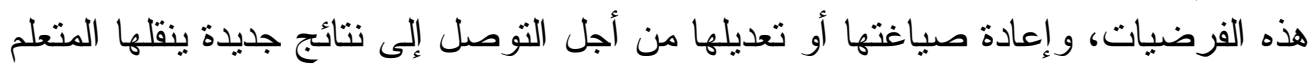

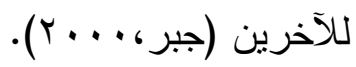

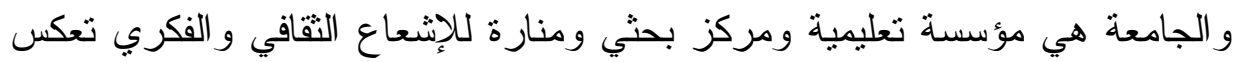

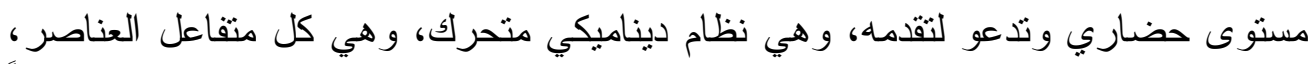

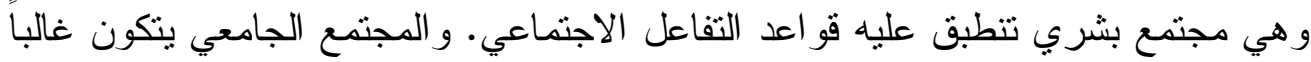

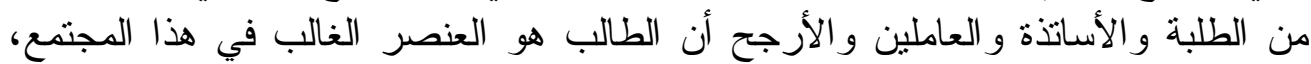

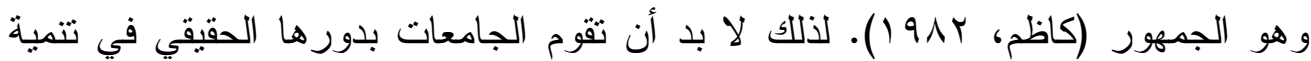

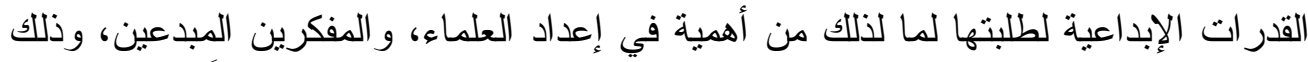

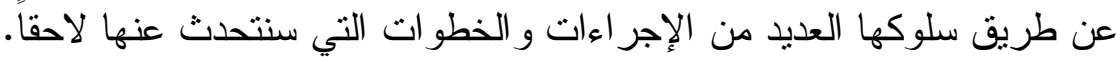

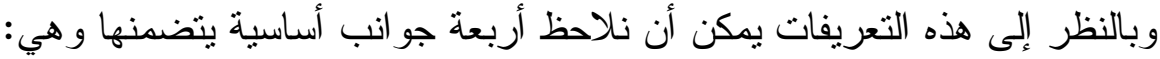
1- أند يمكن النظر إلى الإبداع الطلابي باعتباره عملية تتم من قبل الجامعة سو اء كاء كانت

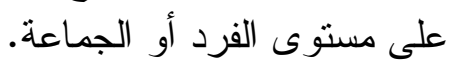

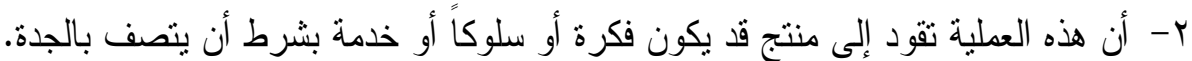

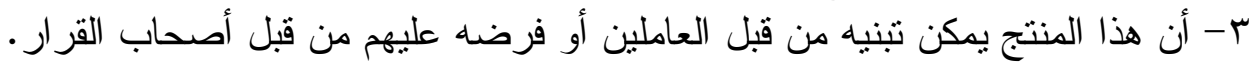

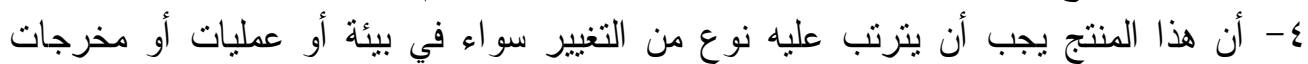

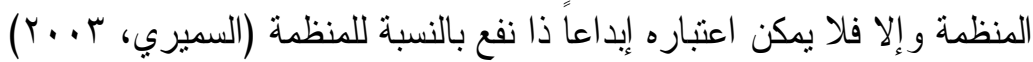

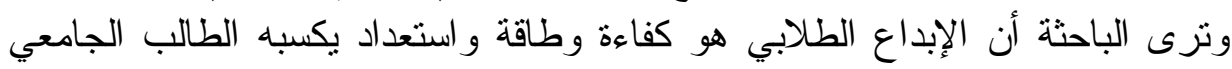
من خلال التركيز المنظم على دعم قدراته العقلية وأرادته وتجاربه ومعلوماتهاتها، ويمكن صاحبه من كثف سبل جديدة في العالم الذي يحيط بنا و الخلاص من الملل و التكر ار ، لذللك يصبح الإبداع المادة الأساسية عند الطالب الجامعي في عمليات التغيير و التطوير .

\section{أهمية التفكير الإبداعي للطلبة الجامعيين و الجامعات:}

إذا وجد التفكير الإبداعي لدى الفرد بطريقة ثابتة نسبياً، يصبح هذا أسلوب يميزٍ

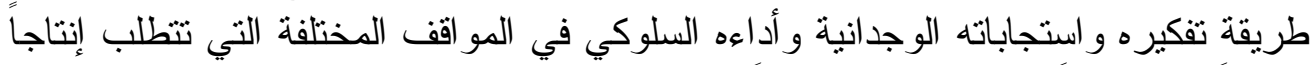

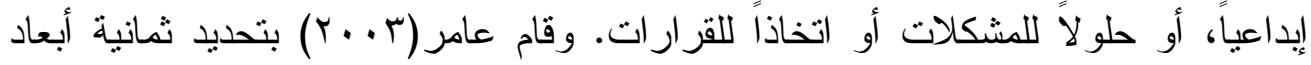

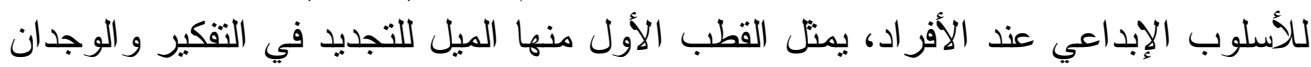

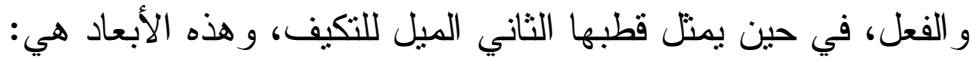

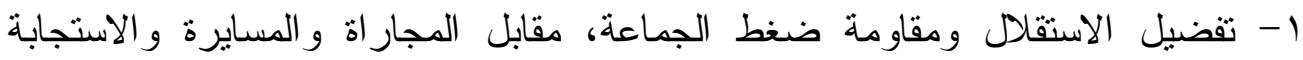

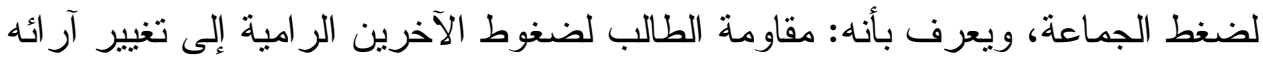
أو أفعاله، مع عدم الانشغال بآر ائهم و أحكامهم. 
r- تفضيل التجديد والاختلاف، مقابل تفضيل التقليد وما هو مألوف ومعتاد، أي ميل

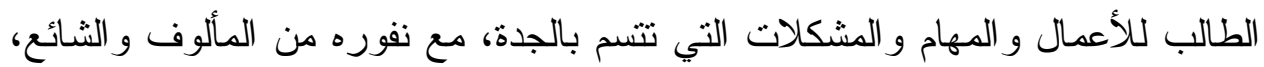

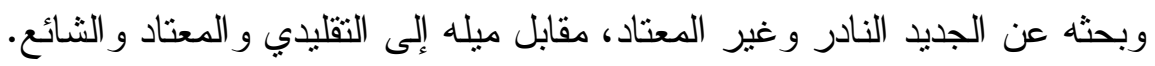

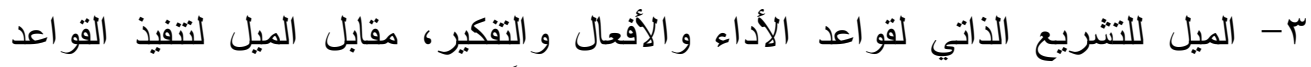

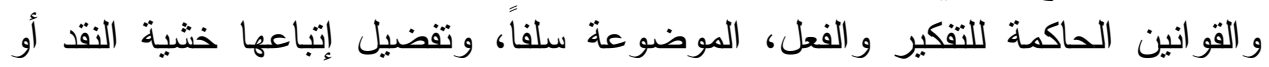
الخطأ.

ع - تفضيل الافتراق و التشعب في التفكير، مقابل تفضيل التفكير التقاربي موحد الاتجاه،

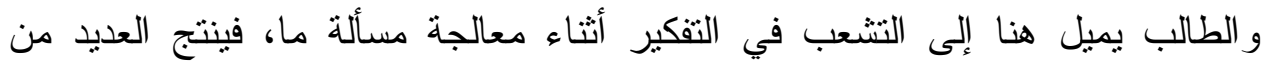
الأفكار المتتوعة، مع المرونة في التتاول، مقابل الميل لإنتاج عدد محدد من الحلول التول والاقتصار على المحاور الأساسية.

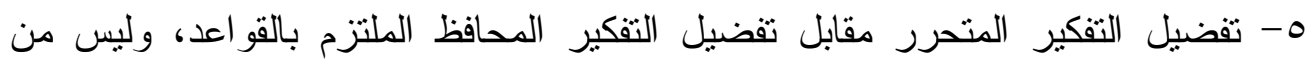

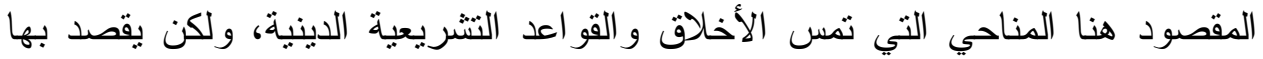
القوالب و القو اعد الإجرائية التي تحدد سلفاً من القائمين على الأمر كالأساتذة أو الزماء التهاء

$$
\text { المتمسكين بهذه القو اعد كما هي. }
$$

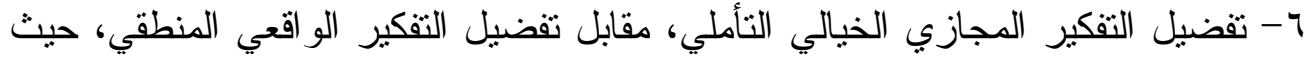

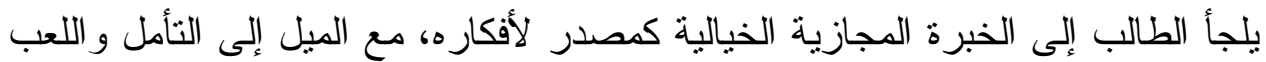
بالأفكار واختلاق العلاقات غير المعتادة بين الأثياء.

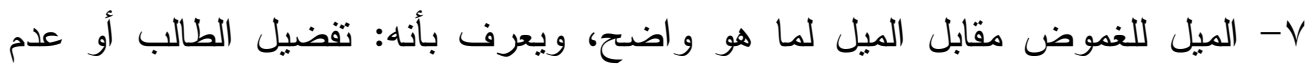

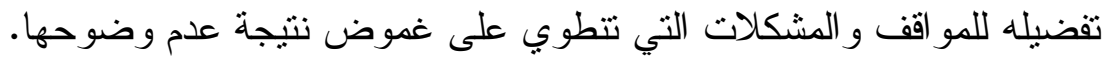
1- تفضيل المعالجة الكلية التركيبية للمعلومات و المهام، مقابل تفضيل المعالجة التحليلية

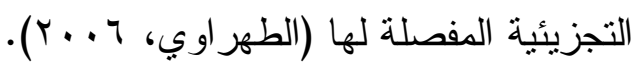
وتتفق الدر اسات في مجال الإبداع على أهميته للمؤسسات التربوية لمات لما يحققه من مز ايا

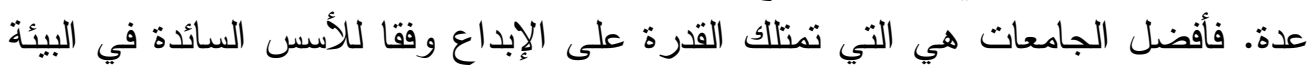

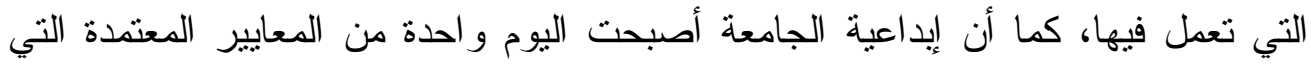

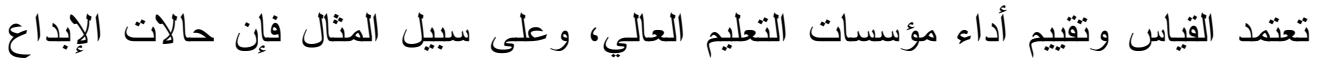

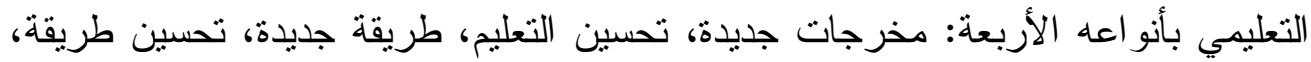
أصبحت ضمن فقر ات المقاييس المختلفة التي تنتخدم لتقييم الأداء.

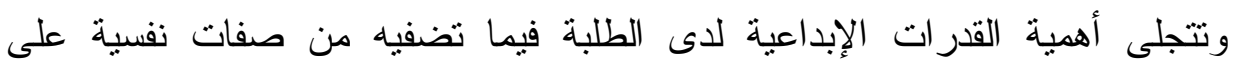

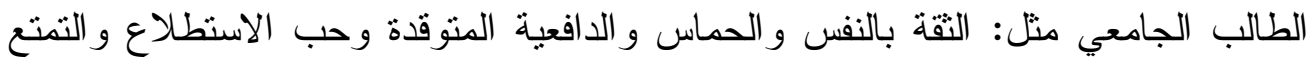

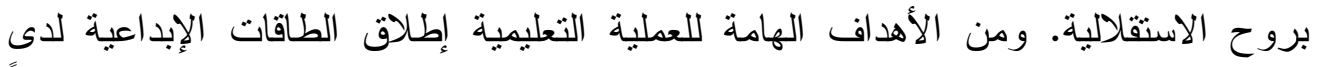
الطلبة، ولو حاولنا أن نجمل أهمية الإبداع في نقاط محددة، فإنه سيحقق على الألى الأقل بعضاً

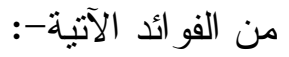


ا ـ تحسين نوعية التعليم(Schemerhom, et al.,1997) ذلك من خلال المرونة والتكيف لحاجات الطلبة.

r. تحسين المخرجات( Goldhare,1986) و وذلك بتحقيق الكفاءة و الفاعلية في الأداء و إنجاز الأهداف و استخدام المو ارد و الطاقة بشكل نربوي. r. زيادة قدرة الجامعات على المنافسة وذلك من خلال:

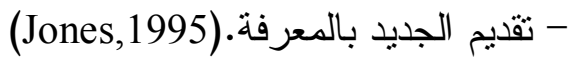

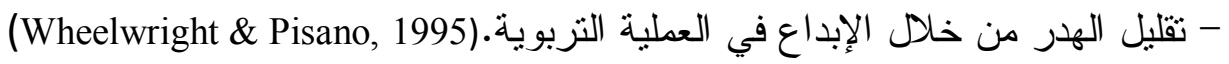

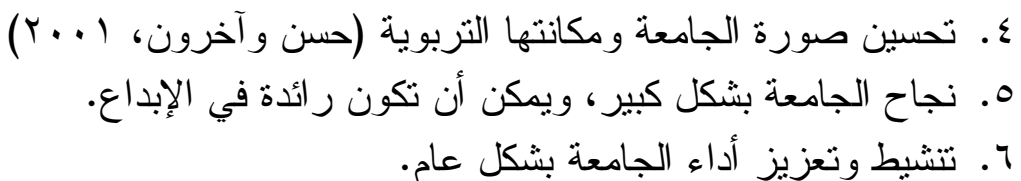
V. . مساعدة الطلبة ليصبحو ا أعمق فهماً و إدر اكاً وتحقيقاً لذاتهم وقدر اتهم الإبداعية.

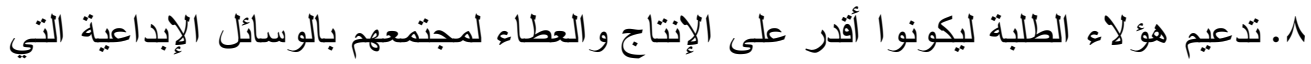
تشهم في تشكيل و اقع جديد. 9. تخليص الطالب من تأثثر الأفكار السلبية التي تكرس الجمود الفكري، وعدم التجديد

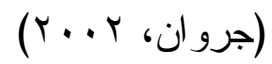

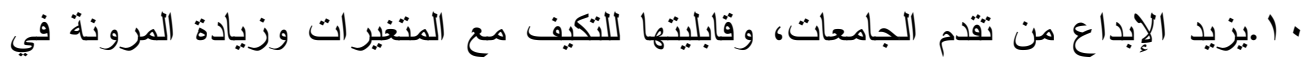

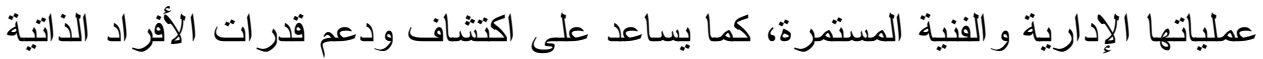
وتوجيها نحو تطوير الجامعة. 1 ا.يساعد الإبداع في تحقيق الذات و الثشعور بالإنجاز لجميع العاملين في الجامعة، وتطوير

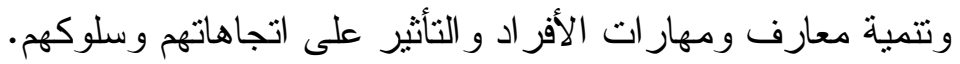

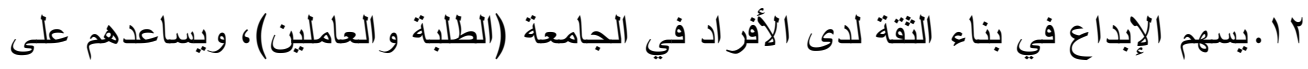
التظلب على المعوقات الثخصية التي تحول دون قدرتهم على التعبير عن إمكاناتهم الإبداعية.

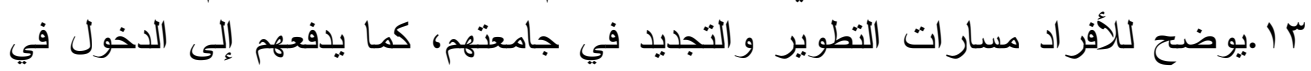
منافسات التحدي و التميز مع الآخرين. ـ ا .يساعد الإبداع الطلبة في إعادة تحديد أهدافهم وتصور اتهم عن الجامعة، وبالتالي قدرتهم على الظهور بصور إبداعية متجددة ومستمرة.

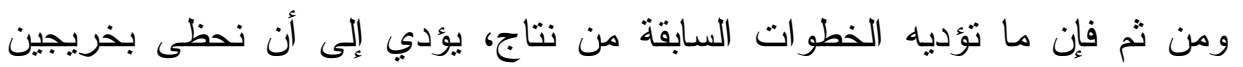

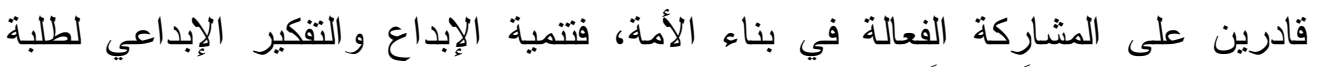

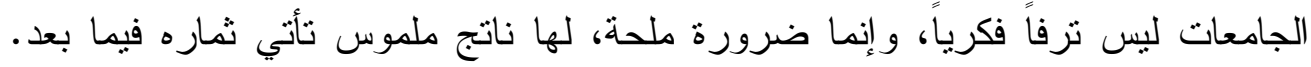

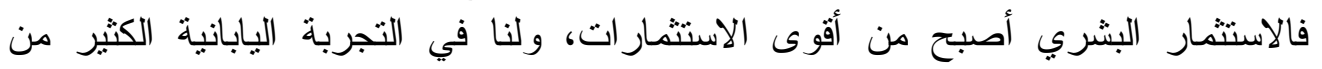

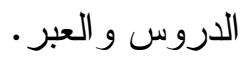




\section{دور الجامعات في تطوير التفكير الإبداعي للطلبة:-}

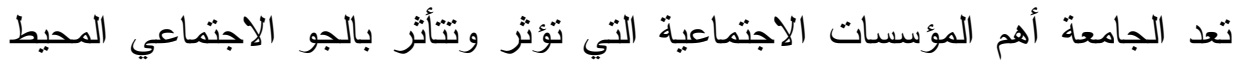

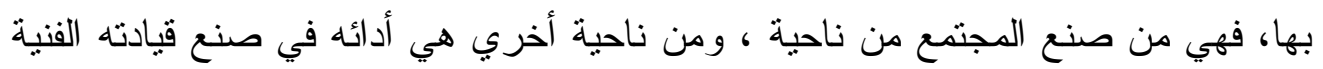

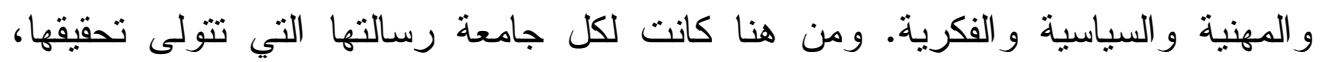

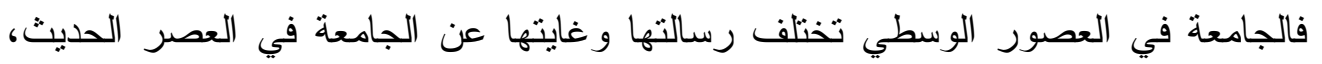

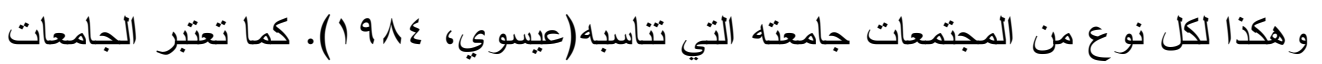

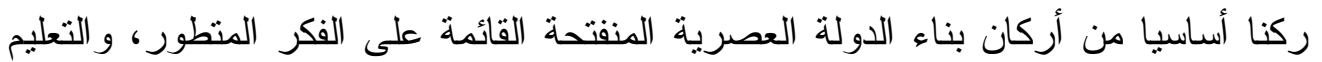

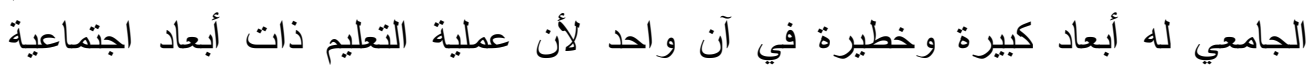

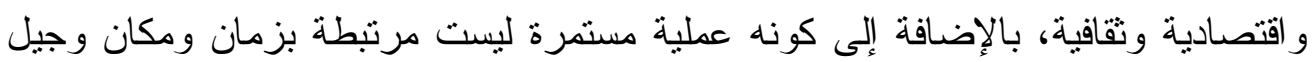

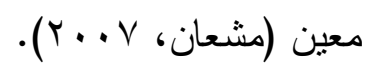

إن الجامعة في أبي مجتمع لا يمكن أن تؤدي دورها الكامل في التغيير الاجتماعي

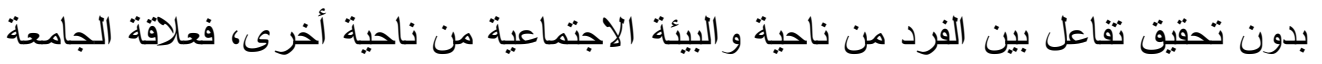

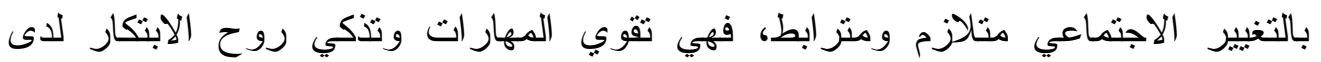

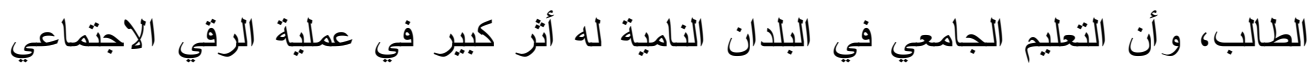

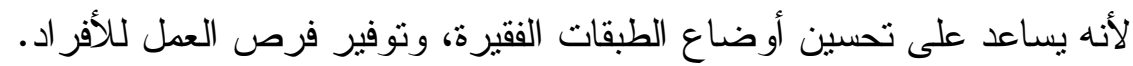

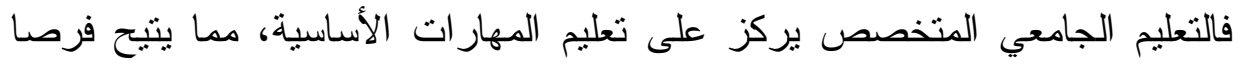

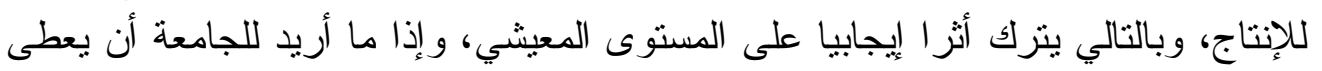

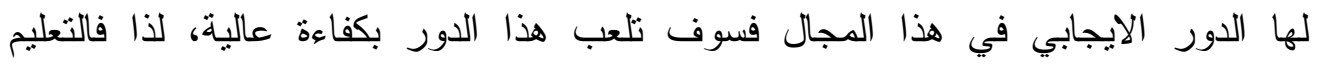

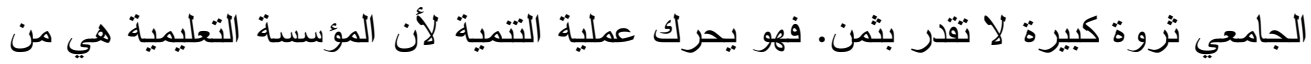

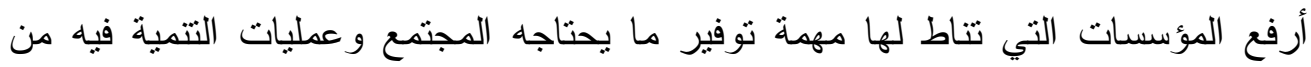

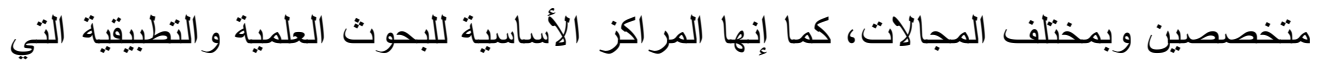

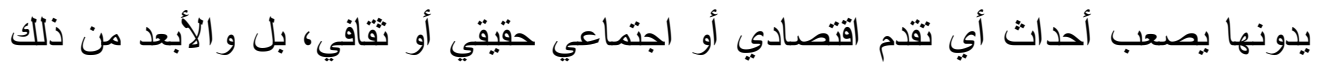

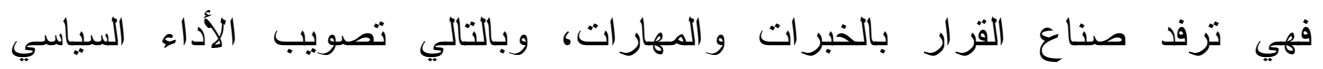

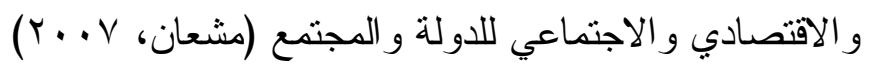

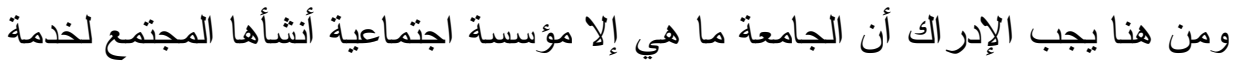

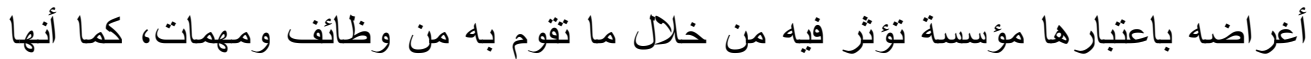

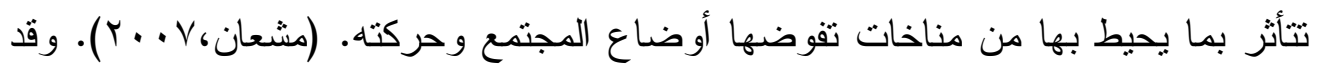
صنف البعض مجالات خدمة المجتمع إلى نو عين: أو لا: داخل الجامعة: وتتلخص في المشاركة في الدئه الهناشط الطلابية غير الدراسية، وتوجيهها حسب دجالات اهتمام عضو هيئة التدريس أو هواياته في الثئون الثقافية 
و الاجتماعية أو الرياضية أو الفنية وغير ذلك، أو ما قد يقام من معسكرات للخدمة موجهة

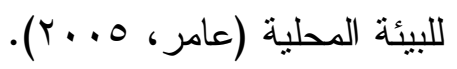

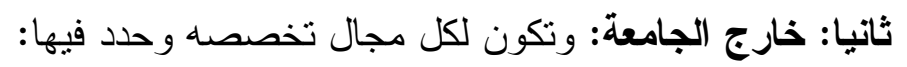

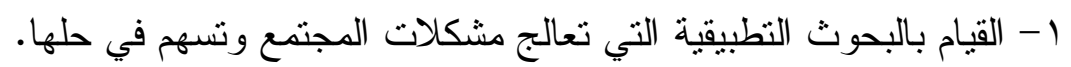

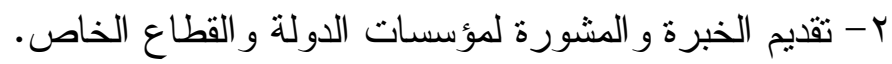

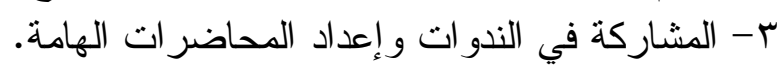
ع - الإسهام في الدورات التدريبية لتأهيل العاملين في الدولة.

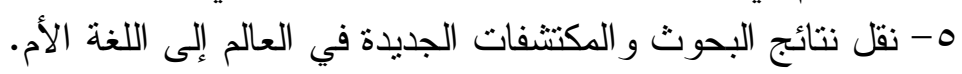

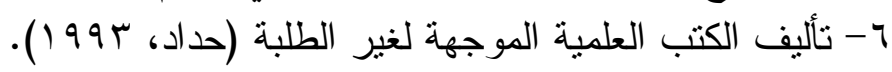

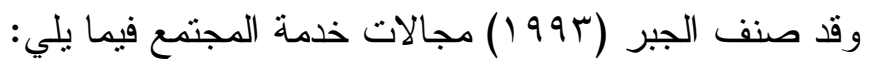

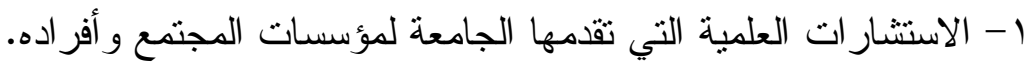
r- التدريب و التعليم المستمر الذي تقدمه الجامعة للكو ادر الوظيفية التهية. r- البحث النطبيقي الذي يسعى إلى در اسة مشكلات المجتمع ومؤسساته و العمل على حلها.

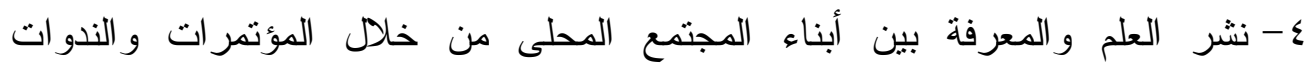

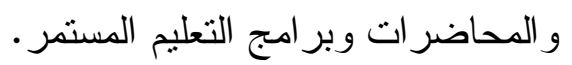

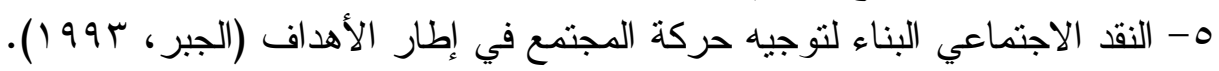

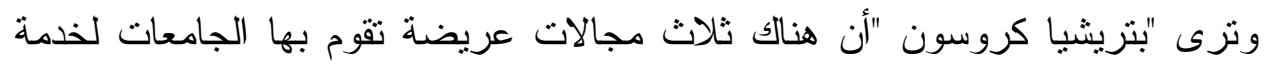
المجتمع وهى كالتالي.

1- الخدمة التي تقدمها الكليات أو الجامعات وهى ما تقوم به اللجان و التتظيمات داخل

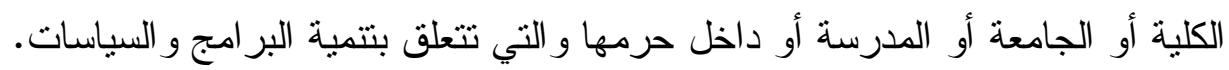

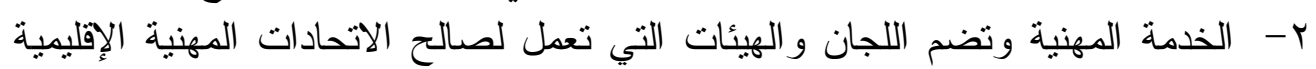
منها القومية أو الأمور الأكاديمية.

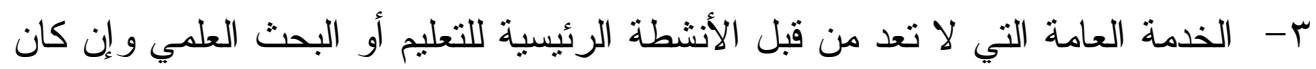

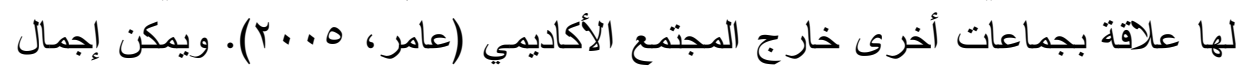

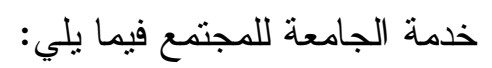

- إعداد العنصر البشرى القادر على إحداث التتمية المنشودة من خلال إعداد القوى العاملة

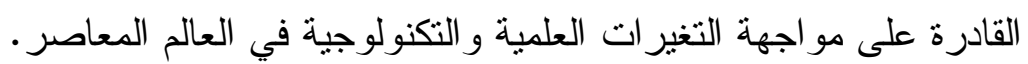

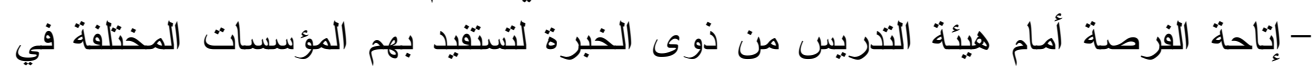
مجالات الإنتاج و الخدمات.

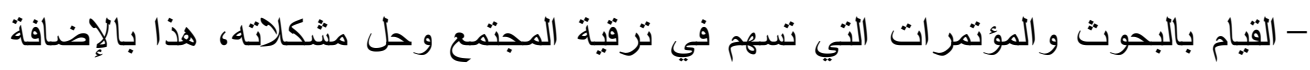

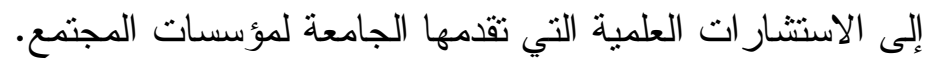


- تعليم الكبار من جميع الأعمار (التعليم المستمر) و التدريب المستمر للمهنيين لرفع كفايتهم

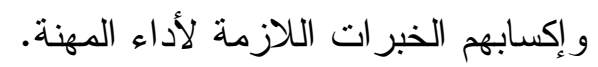
- نشر العلم والمعرفة بين أبناء المجتمع المحلى من خلاء النداءل الندوات و المحاضرات التي تساعدهم على حل مشكلاتهم و التكيف مع مجتمعهم.

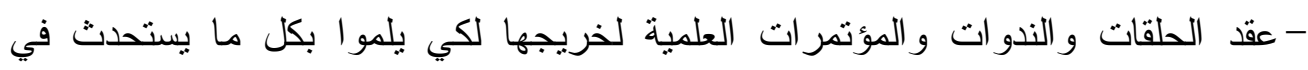
مجالات تخصصهم ومعالجة المشكلات التي تو اجهرم في الحياة العلمية.

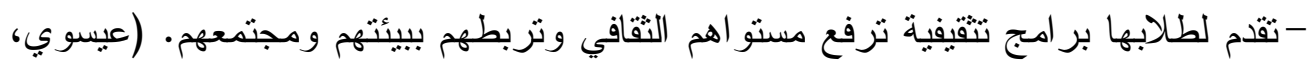

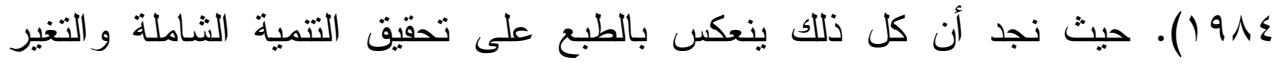

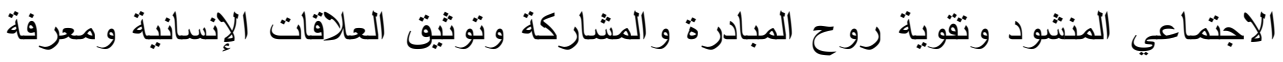

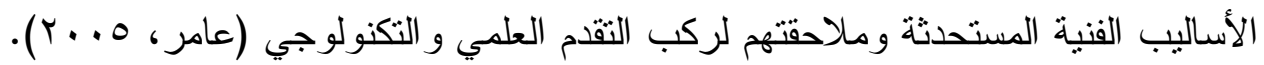

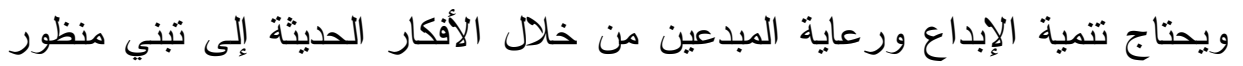

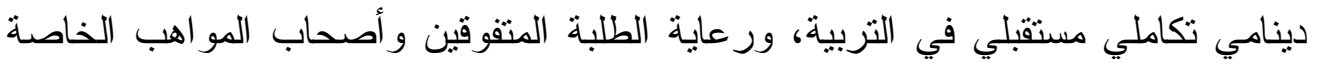

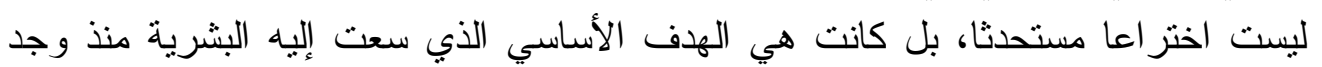

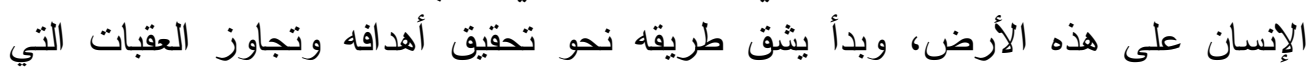
تو اجهه، و ابتكار الأساليب التي نساعده على الوصول إلى تلى تحقيق أهدافه بما في ذلإنك إعمال الفكر وتشغيل الخيال وتتشيط الدافعية.

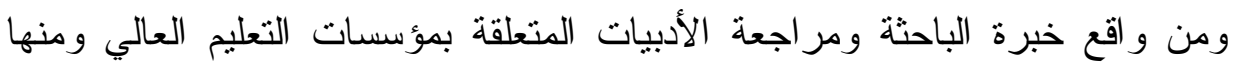

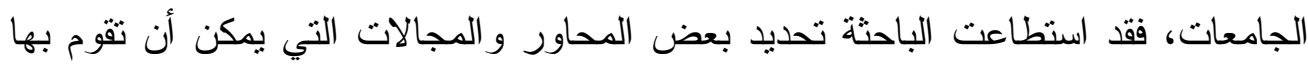

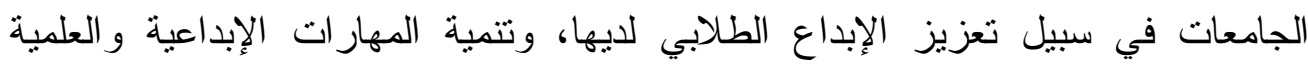
و الفكرية لهم، وذللك من خلال المحاور التالية:

المحور الأول: الأهداف والسياسات والاستر اتيجيات:

و الأهداف هي الغايات المراد الوصول إليها من قبل الجامعة، وهي تتعلق بالمستقبل

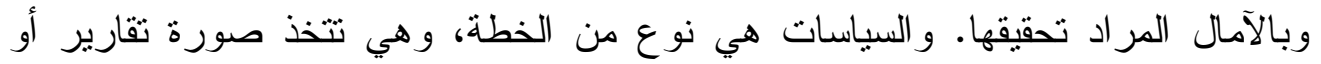

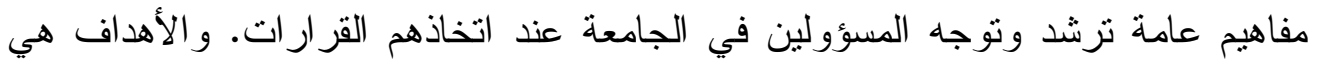

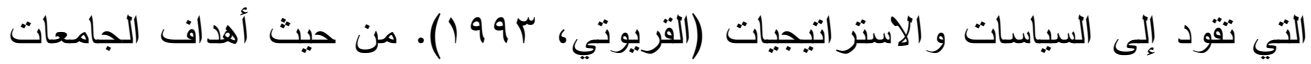

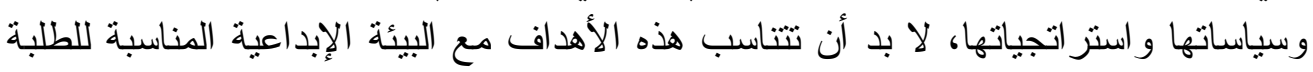
وأن تكون على النحو التالي:

1. تهدف الجامعة إلى إكساب الطلبة الاستقلالية و القدرة الإبداعية.

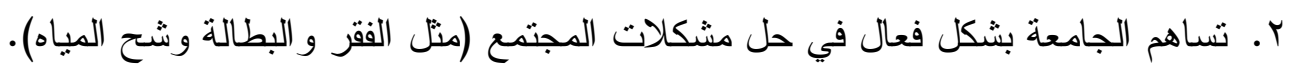

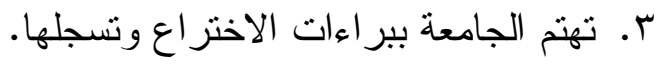
ـ. تهدف الجامعة إلى ربط التعليم بمتطلبات التتمية و التقدم. 
ه. تشجع الجامعة البحوث التي نزكز على حاجات المجتمع.

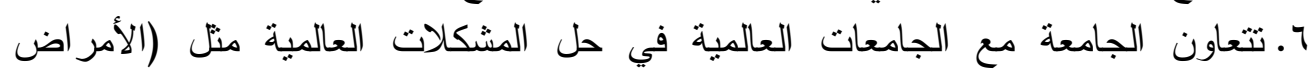

$$
\text { و التلوث و الفقر و الأمية و الجفاف). }
$$

V. نحقق أهداف الجامعة عن طريق جدول زمني محدد ودقيق.

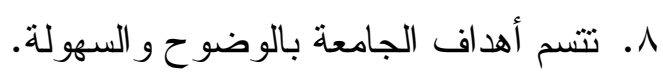

9. تهدف الجامعة إلى نشر ثقافة الإبداع بين الطلبة والعات العاملين.

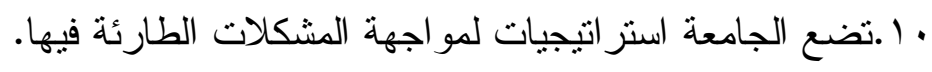

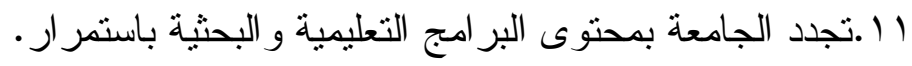

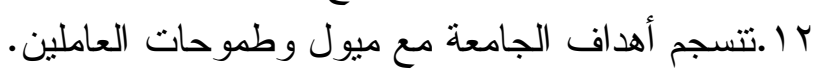
المحور الثاني: التثريعات والقوانين والأظمة: -

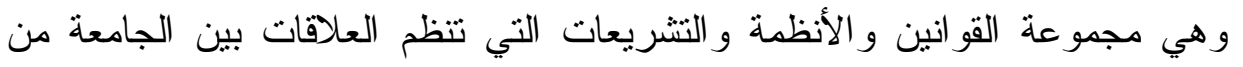

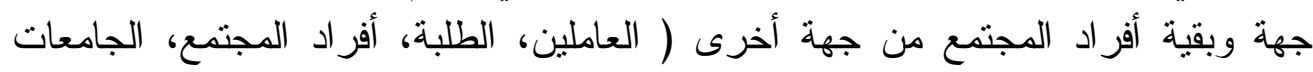

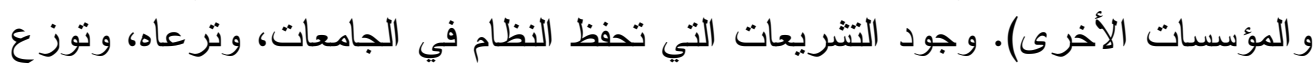

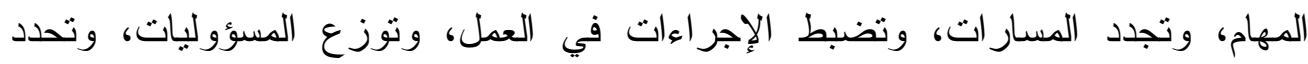

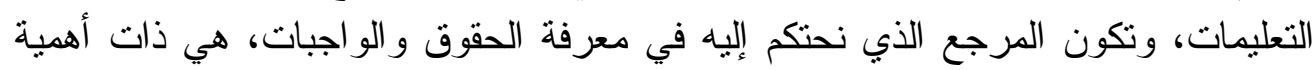

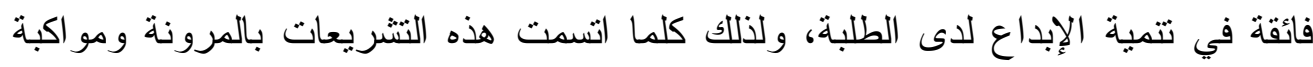

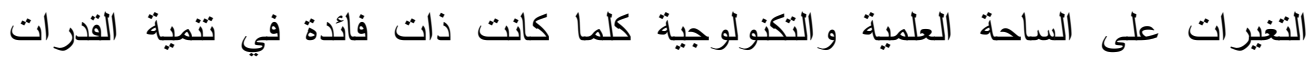

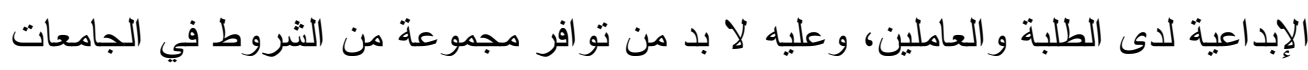
التي تدعم الإبداع، ومنها على سبيل المثال:

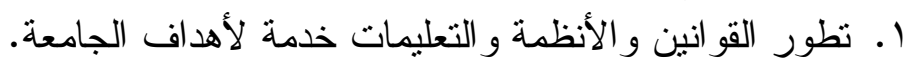

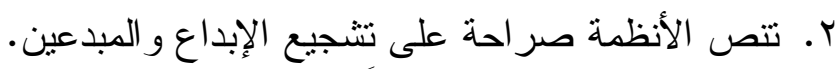
r. بيتم مر اجعة التشريعات دورياً لمو اكبة التقدم العلمي. ع. تـثق ممارسات العمل مع القو انين الأنظمة و التعليمات.

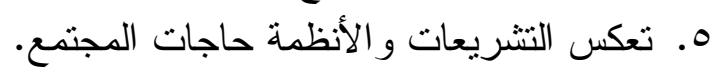
7 7. تكون التشريعات مفهومة من قبل العاملين و الطلبة.

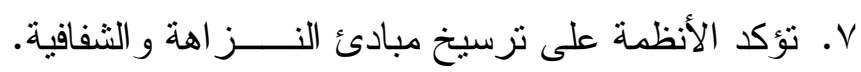

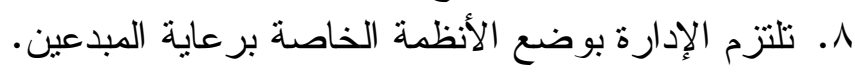
9. تتص الأنظمة و التعليمات على محاربة الفساد الإداري و المالي. 
المحور الثالث: الهيكل التنظيمي.

يشمل الهيكل التنظيمي حجم الجامعة، ونمط السلطة، ونمط اتخاذ القر ار ات فيها. وذلك أن طبيعة الهيكل التنظيمي ونظرة العاملين في التنظيم إليه تؤثر في قدرنهم على المشاركة و الإبداع.

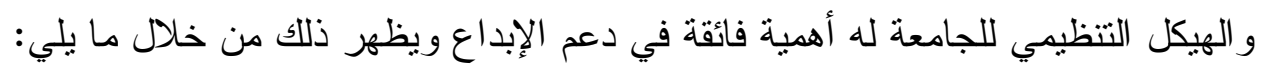
ا. ب. ترتبط الرتب الوظيفية في الجامعة في الهيكل التنظيمي بالكفاءة. r. بضع الهيكل التنظيمي وصفا للأدو ار الوظيفية.

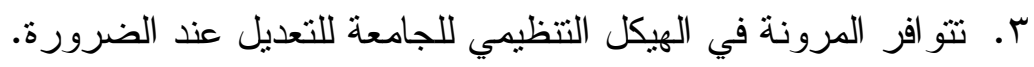

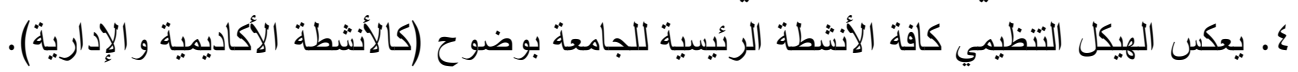

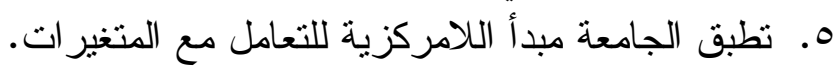

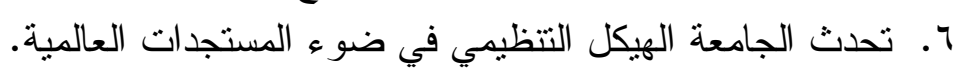

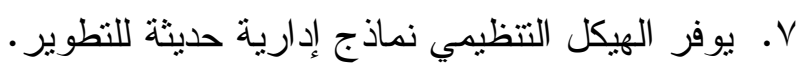

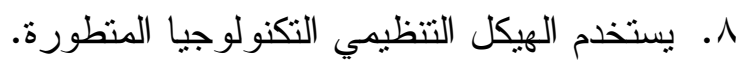

9. تبسط الجامعة إجر اءات العمل في دو ائرها المختلفة (مثل شؤون التون العاملين و المالية و القبول).

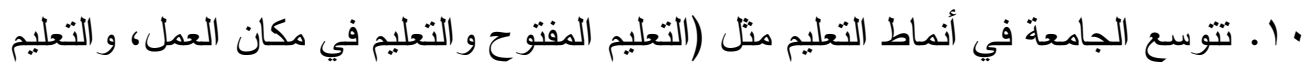

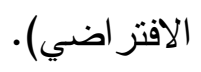

\section{المحور الر ابع: البيئة التنظيمية للجامعة.}

هي ما يو اجهه الفرد في البيئة الجامعية من مؤثرات ذات أثر في العملية التعليمية،

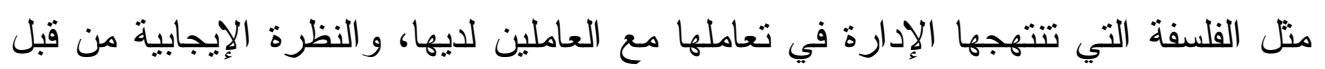

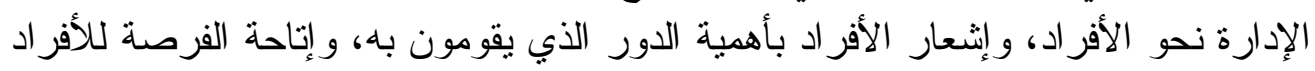

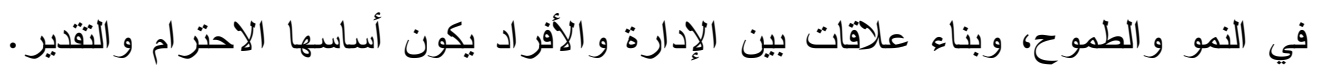

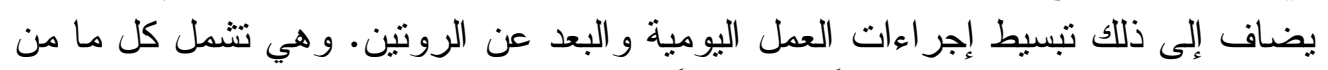

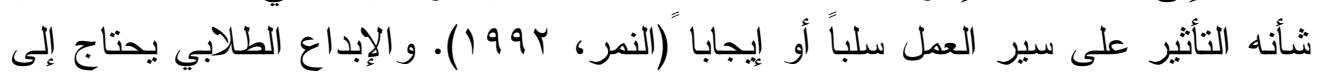

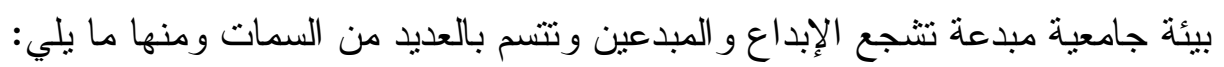

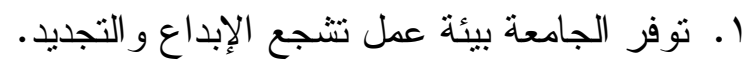
r. تحتضن الجامعة المبادر ات الفردية و الجماعية. r. تؤمن البيئة الجامعة بقدرة الأفر اد على التعلم. ع. تتوفر النظرة الإيجابية من قبل الإدارة للأفراد.

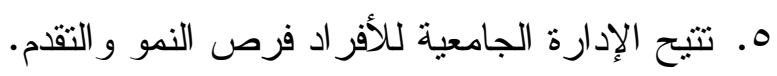

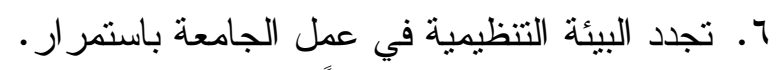

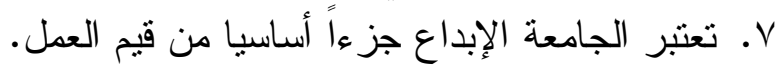




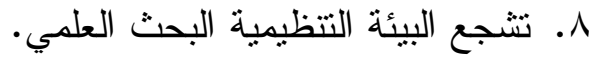

9 ـ . توفر الجامعة قنوات اتصال مفتوحة داخل الجامعة وخارجها.

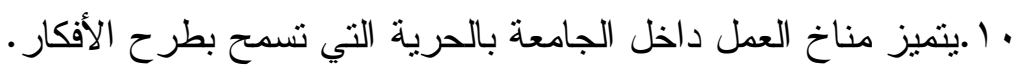
ا ا.يتميز مناخ العمل بالتعاون و الاحتر ام المتبادلين بين العاملين.

\section{المحور الخامس: القيادة الإدارية}

مهما أختلفت المفاهيم التي تتاولها الباحثون للقيادة فقد اتفق الجميع على اعتبارها

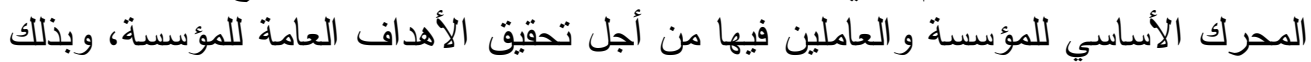

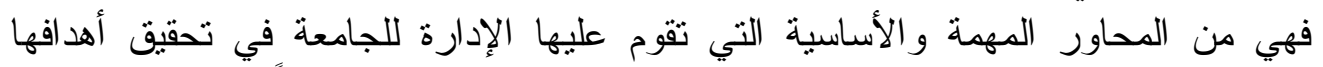

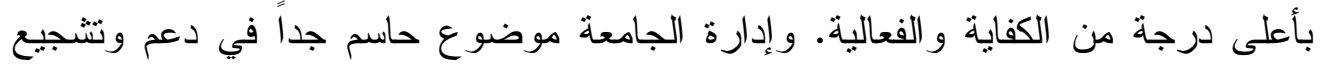

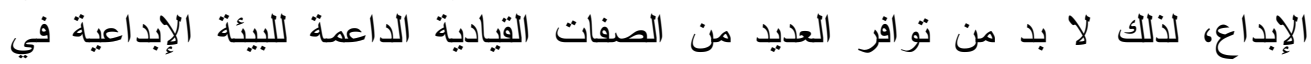

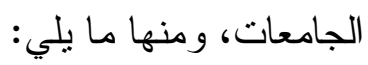

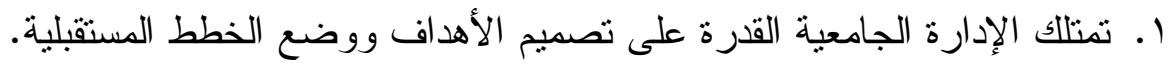

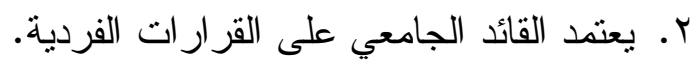

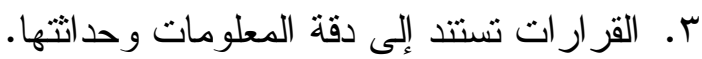

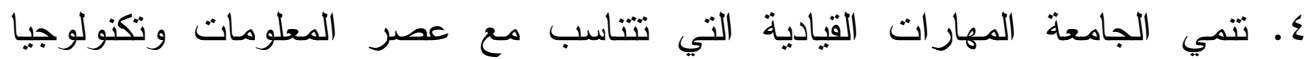
الاتصالات.

ه. تضع إدارة الجامعة أساليب علمية للكثف عن المواهب الإبداعية المبكرة و إعدادها لالمستقبل. 7. تتميز الإدارة بالفهم العميق للعملية الإبداعية.

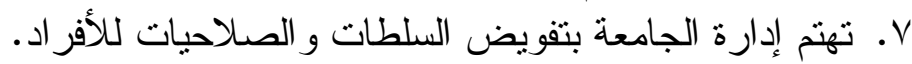

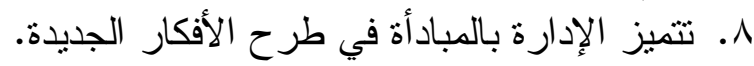
9. تشرك الجامعة العاملين في التخطيط الاستر اتيجي. • ا.تتميز القيادة الجامعية بالأمانة و العدالة و النز اهة.

المحور السادس: إدارة الموارد البشرية و المادية والمالية:--

تعتبر هذه الإدارة هي الركيزة الأساسية وحلقة الوصل بين مختلف الإدارات

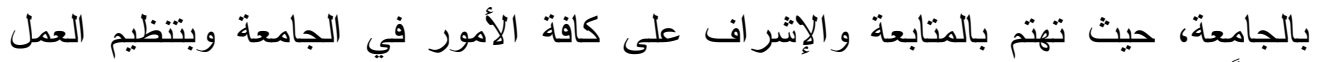

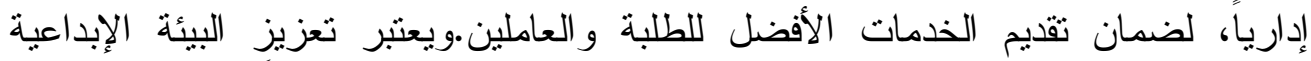

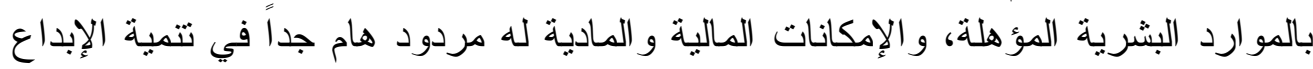

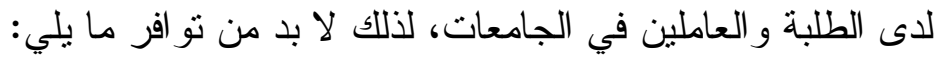

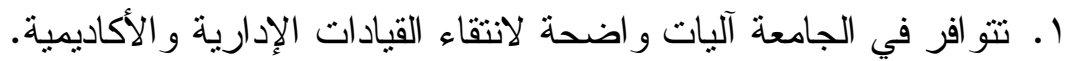

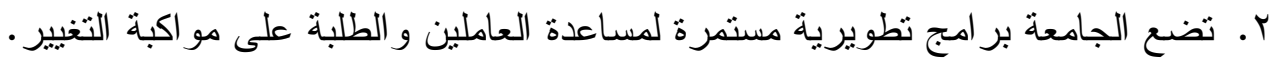

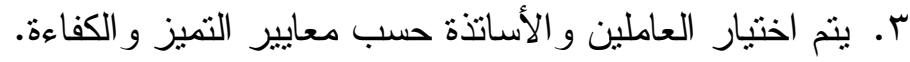


ـ. تبتدع الجامعة وسائل تمكنها من نقييم أداء العاملين.

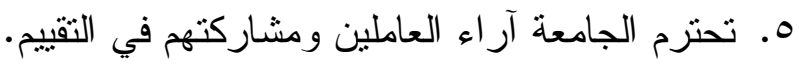

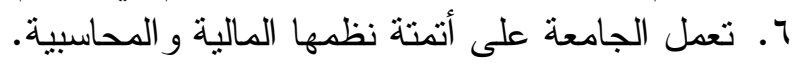

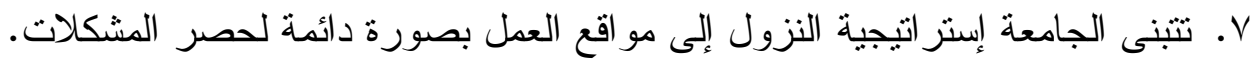

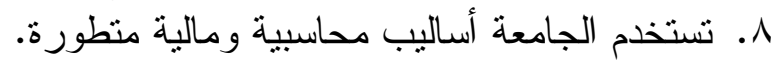

\section{المحور السابع: إدارة نظم المعلومات: -}

تعتمد جميع وظائف الإدارة الجامعية على المعلومات، و على الاستخدام الفعال لها،

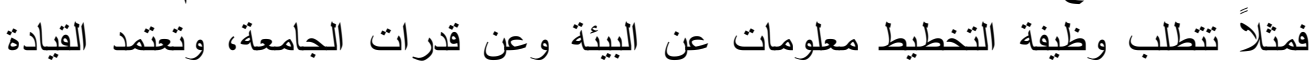

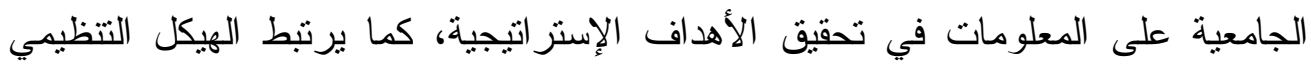

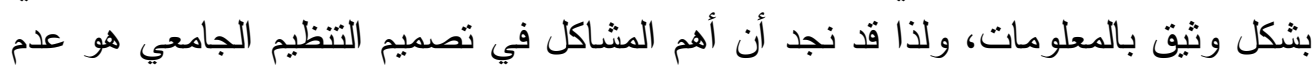

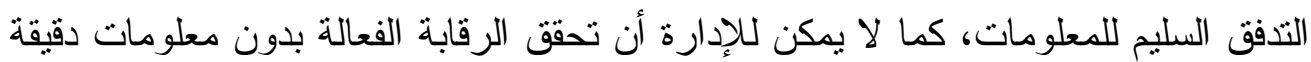

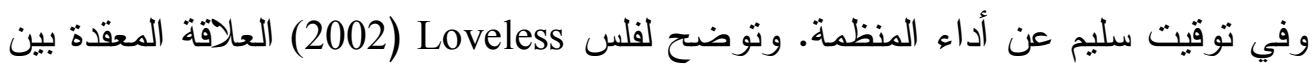

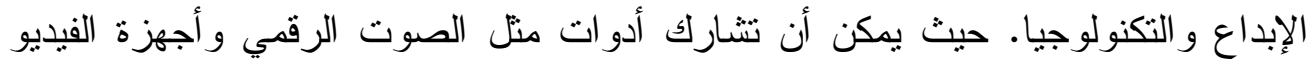

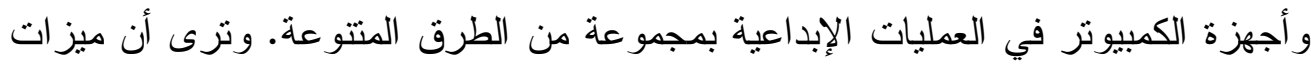

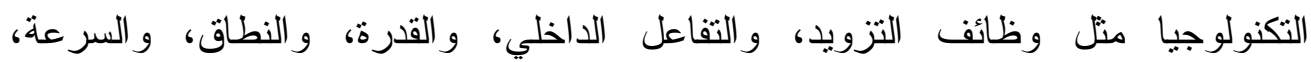

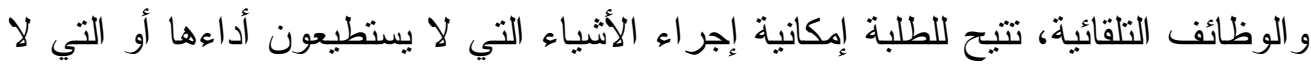
يمكنهم تتفيذها بكفاءة مثلما يفعلون باستخدام التكنولوجيا.

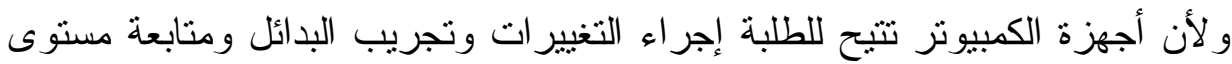

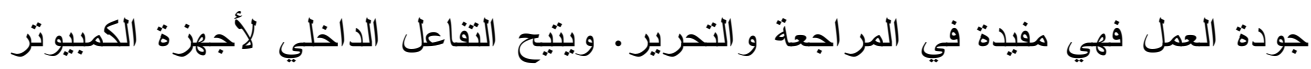

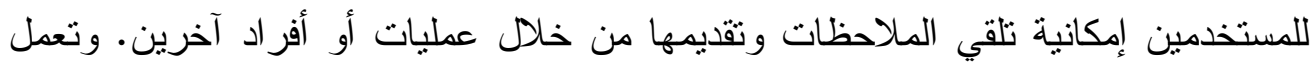

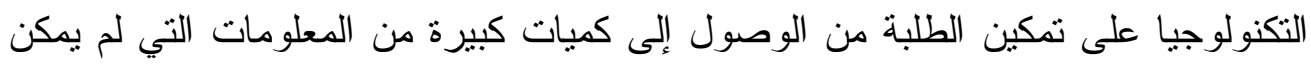

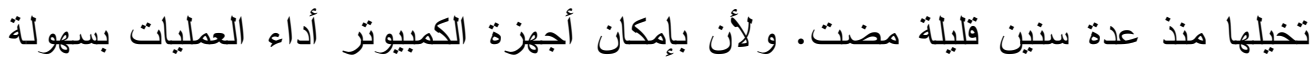

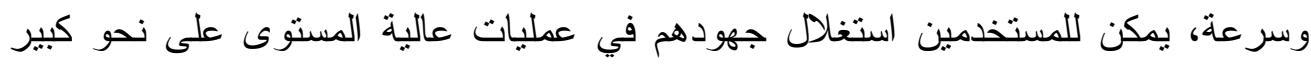

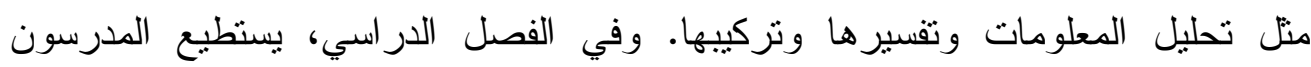

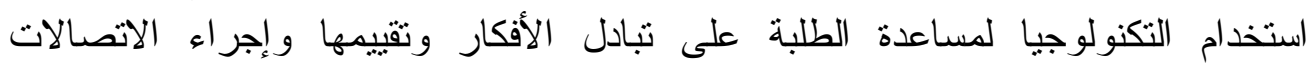

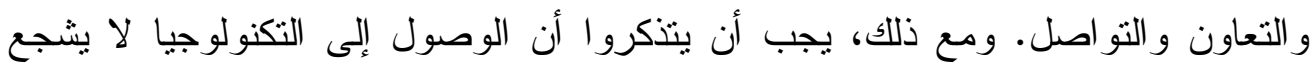

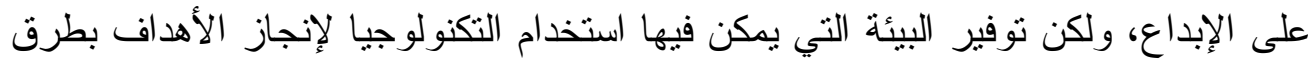

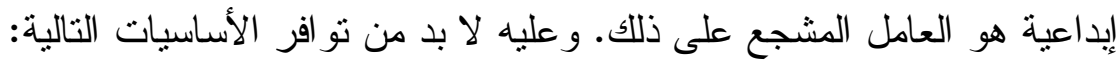
ا ـ تواكب الجامعة التطور العلمي في مجال المعلومات وتكنولوجيا الاتصالات. r. تشتهدف الجامعة استخدام نظم المعلومات و التكنولوجيا لوفيا في استثمار الإبداع.

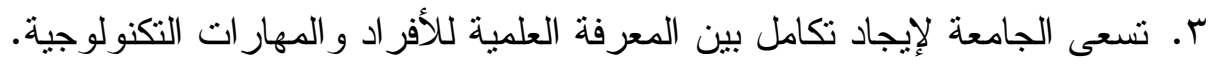


ـ. تسعى الجامعة إلى استقطاب القيادات المبدعة القادرة على إحداث التقدم العلمي و التكنولوجي.

ه. تعمل الجامعة على إعداد العاملين باستمرار لمواكبة الثورة العالمية في إدارة المعلوماتية.

7. تقدم الجامعة للأفر اد الخدمات التقنية في مجالات المعلوماتية وتكنولوجيا الاتصالات. V. تتبنى الجامعة مفهوم التخطيط المتكامل للتطوير منطلقة من تقنيات و أنظمة معلوماتية. ^. ثربط الجامعة مؤسسات البحث العلمي وقواعد البيانات لديها مع نظام المعلومات

$$
\text { المحلي و العالمي. }
$$

9 . تطبق الجامعة المعايير العالمية لاختيار قيادات البحث العلمي و التكنولوجيا.

\section{المحور الثامن: الثر اكة مع قطاعات الإتتاج والخدمات: -}

إن الثراكة تعنى بأوجه التفاعل والتعاون العديدة بين الجامعة من جهة ومختلف القطاعات المجتمعية من جهة أخرى، وتعد هذه النوعية من الثر اكة الثان ذهنية ملائمة و إيجابية

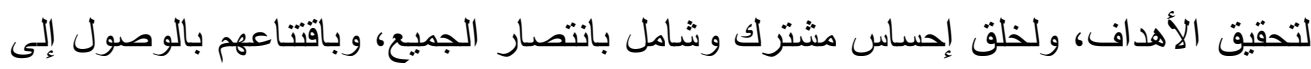

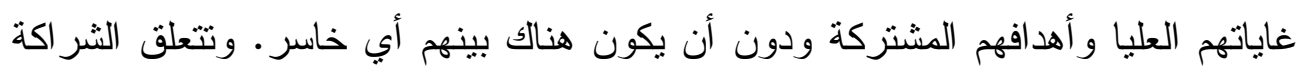

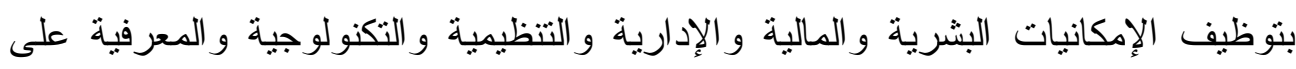

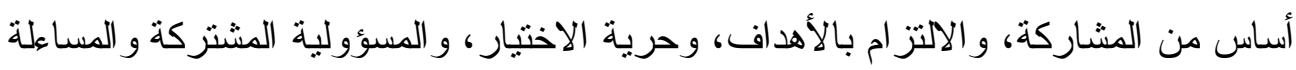

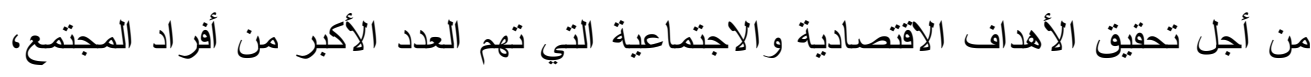

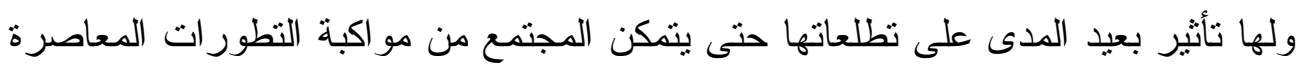
بطريقة فاعلة، وتحقيق وضع تتافسي أفضل. لذلك لا بد أن ينصب دور الجامعة على تطوير هذا المحور من خلافل ما يلي: ا. ـ تتعاون الجامعة مع الأطر اف المستقيدة من الخريجين في تأمين التمويل. r. تنتبى الجامعة خطط مشتركة مع قطاعات الإنتاج لتدريب الطلبة أثناء الدر اسة. r. تشترك الجامعة مع المؤسسات الإنتاجية بإنشاء وتمويل مر اكز بحثية مشتركة.

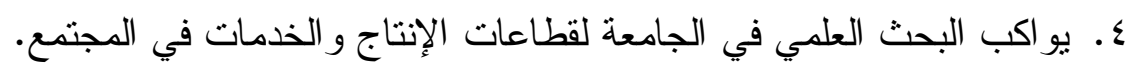

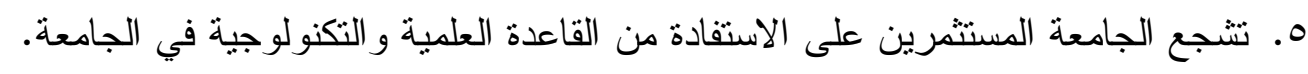

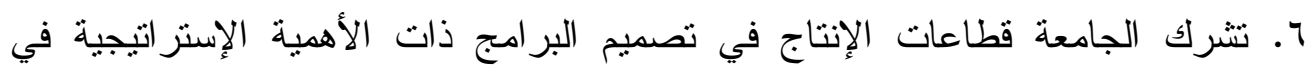
التتمية و التقدم.

V. تستثمر الجامعة الإمكانات البشرية والمادية المتو افرة لديها كمصدر من مصادر التمويل.

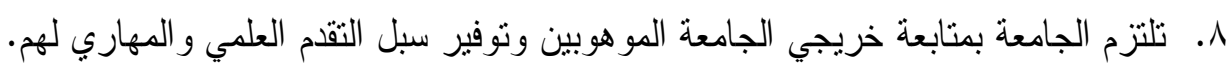
9 ـ تتنبى الجامعة مفهوم الجامعة المنتجة بشكل عملي. 


\section{المحور التاسع: الرقابة والمتابعة والتقويم.}

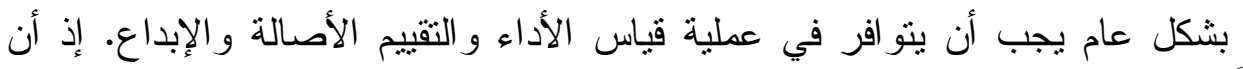

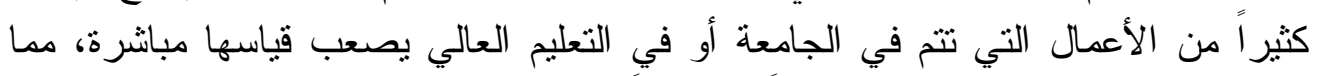

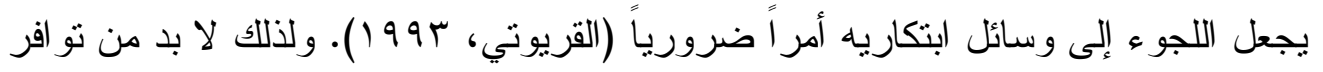
الأمور التالية:

ا ـ بتتم تقييم الأداء على أساس الإنجاز ات.

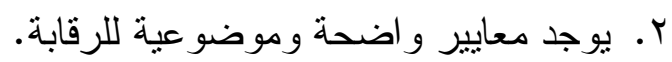
r. تهتم الجامعة بإدارة الوقت و والإحساس بأهمية الزمن.

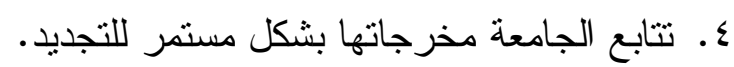

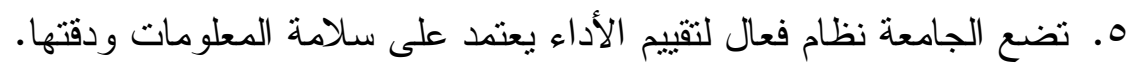
7. تعمل الجامعة على تحفيز المبدعين ومكافأتهر.

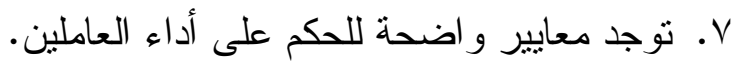

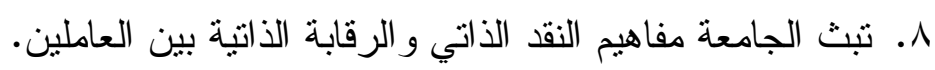

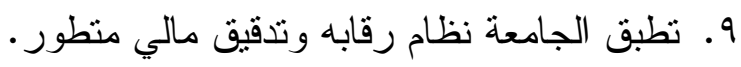

المحور العاشر: دور الأساتذة في تطوير التفكير الإبداعي لطلبة الجامعات:-

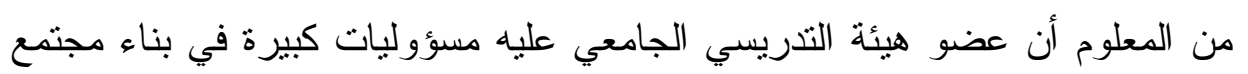

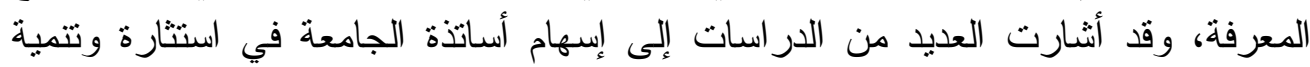

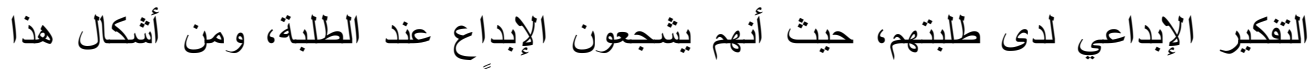

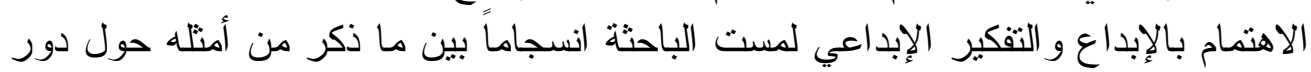

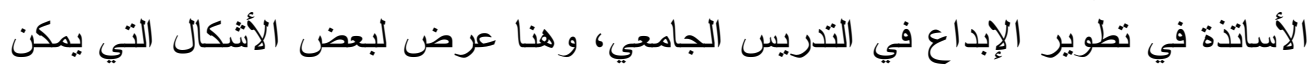

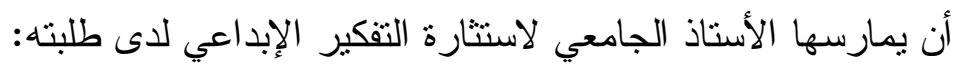

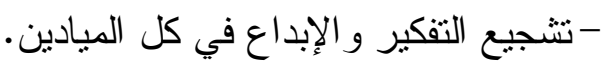
- إجر اء البحوث النظرية و النطبيقية. - تحسين جودة أدائه التدريسي.

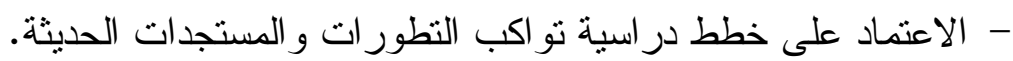
- التتوع في طر ائق تدريسه.

- تحديث في المصادر و المر اجع التي يزود بهان بها الطلبة.

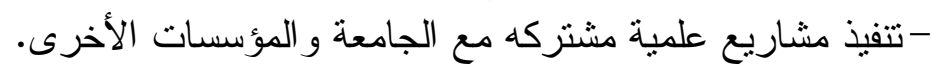

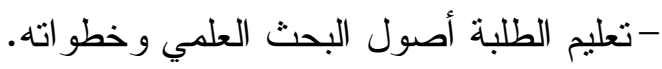

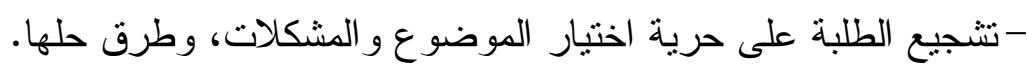

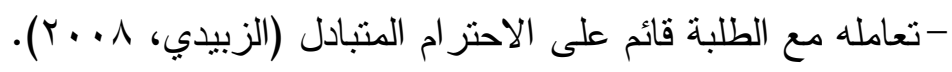




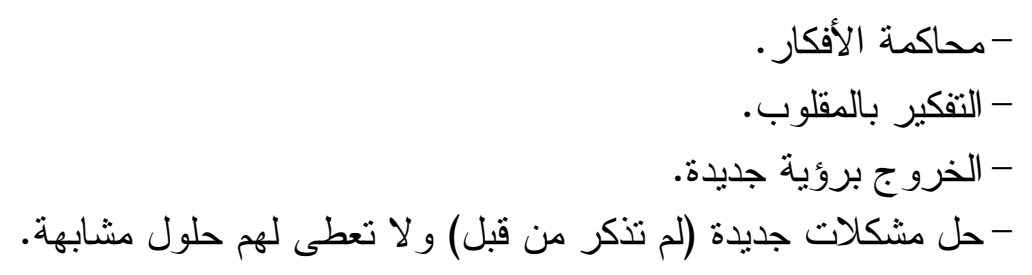

- تصميم بر امج جديدة.

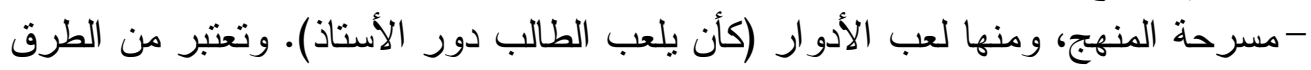

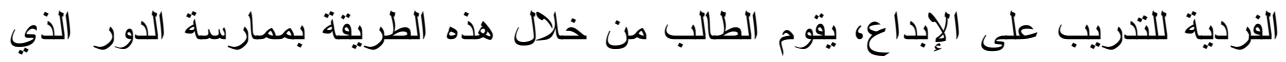

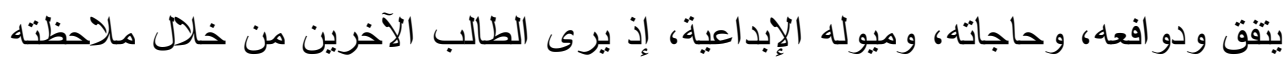

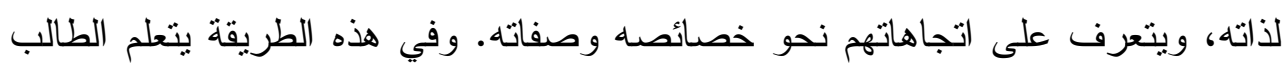

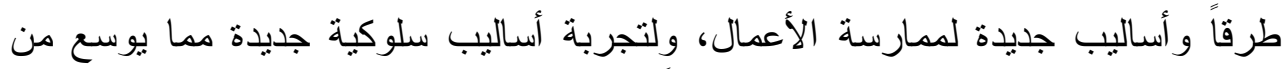

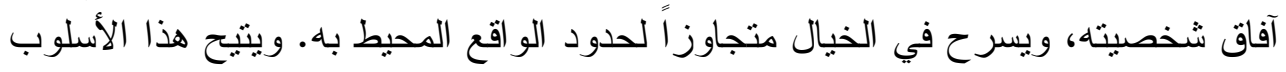

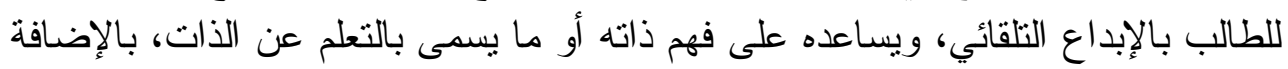

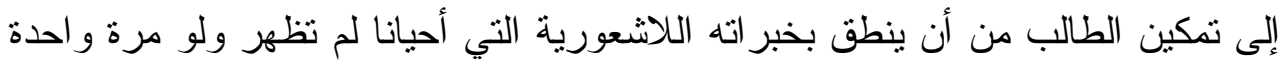

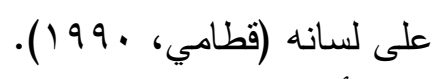

- تقديم أسئلة على شكل مسابقة للطلبة.

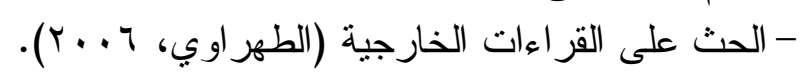

-طريقة العصف الذهني" Brainstorming "، ورغم أنها طريقة النها للتنريب الجماعي إلا أنها

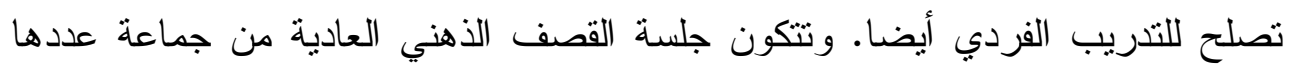

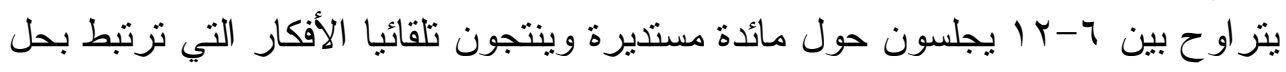

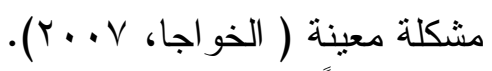

و استتاداً إلى الأدبيات السابقة تقترح الباحثة النقاط التالية التي نزى أن الأخذ بها بسهر في استثارة وتتمية التفكير الإبداعي لاى الطيات الطلبة: 1- العلاقة الطيبة بين الأستاذ و الطالب، القائمة على الحب الإبة و التقدير و الاحتر ام.

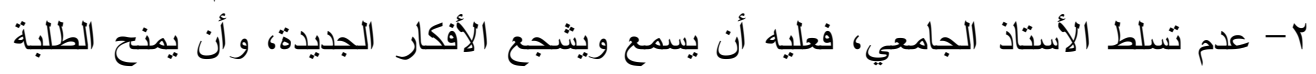

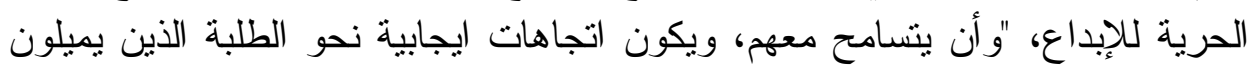

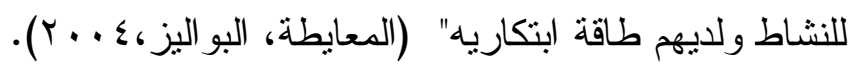

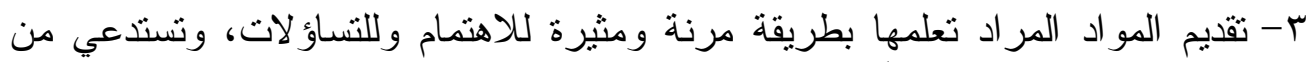

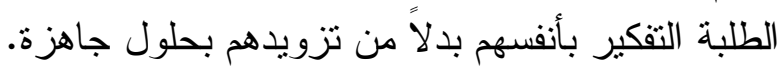

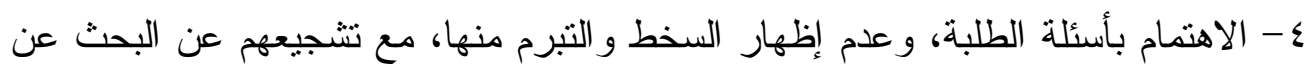
إجابات متعددة. ه- تشجيع الأفكار الثبابية الجديدة و الصائبة، وتقويمها بطريقة إنسانية يغلفها التقدير و الاحتر ام و المودة. - ماع. 
צ- إبداء الارتياح للأفكار الجديدة، والإضافة إليها، و الطلب من الطلبة بذل المزيد من

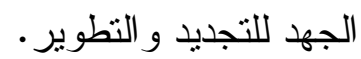

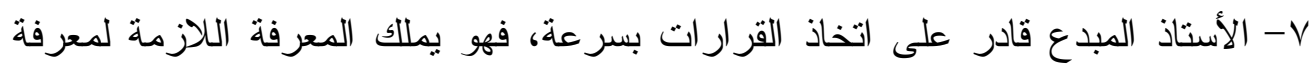
أهية الفكرة المطروحة، ويشجع الطلبة المعنيين لإظهار ها وتطبيقها.

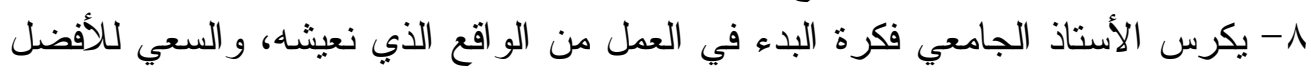

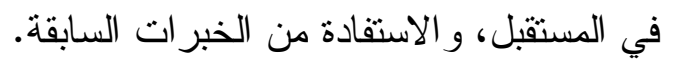

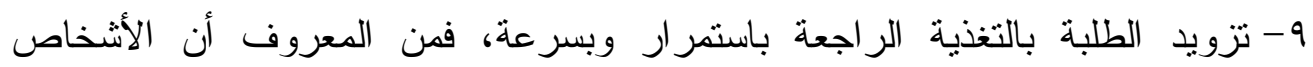

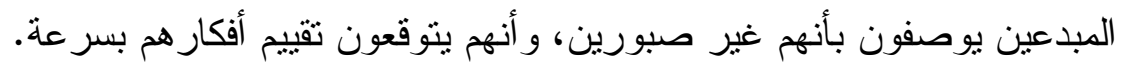

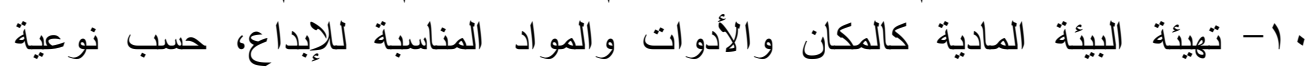

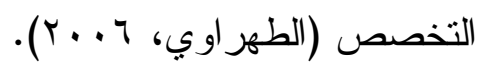

وبذللك تزى الباحثة أن للأستاذ الجامعي الناجح دور كبير ومسؤوليات كبيرة لا يسع

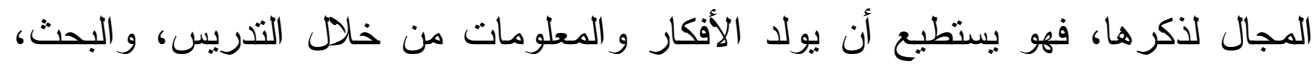

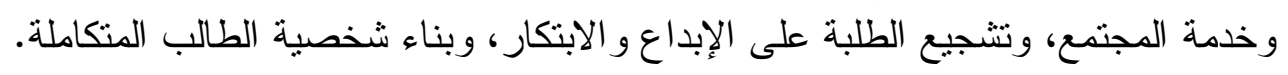

\section{المحور الحادي عشر: دور الصف الدراسي:-}

يكون لبيئة الفصل الدراسي أثر كبير في تثمية القدرات الإبداعية لاى الطلبة. تتضدن

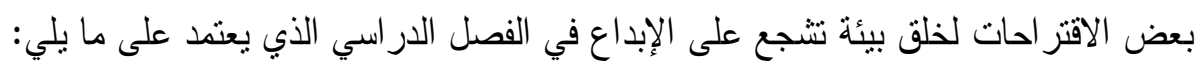

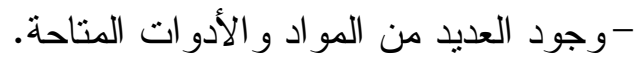

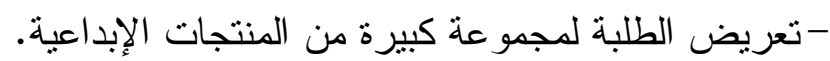

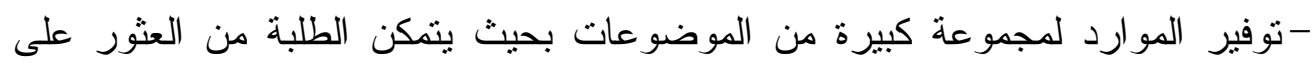
شيء يثير اهتمامهم ويطلق العنان لخيالهم.

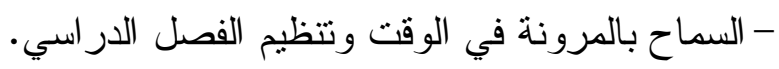

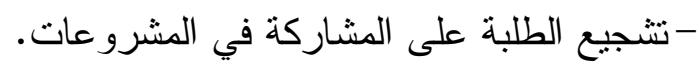

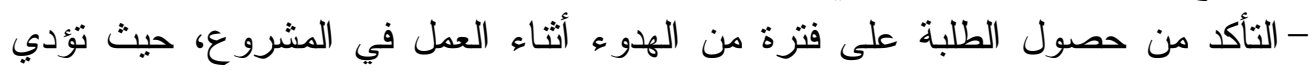
الضوضاء إلى كبت الإبداع.

- تحقيق التو اصل بين الطلبة و الأفراد المبدعينٍ في المجنمع.

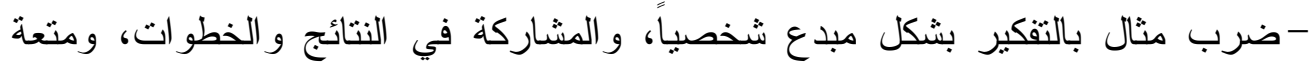
تحقيق الإنجاز ات.

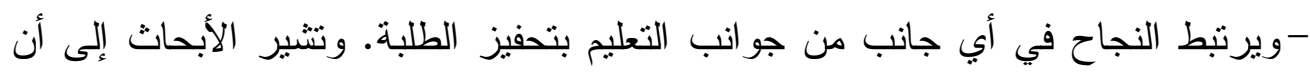
التحفيز الداخلي يعزز من الإبداع بينما يؤدي التحفيز الخارجي إلى بلى تقويضه عمومًا. 


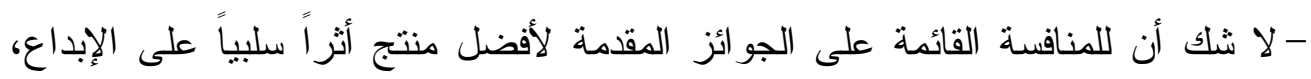

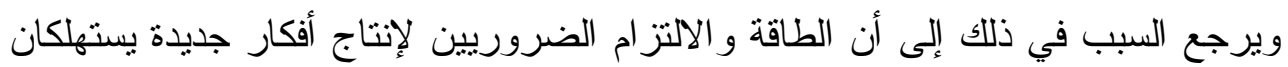
الكثبر من الجهد، وهو ما لا يميل أصحاب التحفيز الخارجي لبذله. (Amabile,1983).

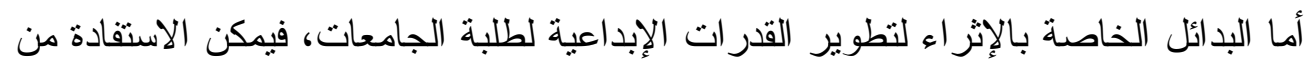

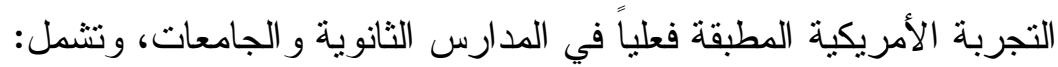

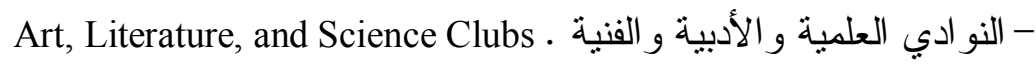

- بر امج تبادل الطلبة. Students Exchange Programs - مشرو عات خدمة البيئة المحلية و المجتمع. Community and Environment Services Projects - المشاغل التدريبية و الندو ات.Symposiums \& Training Workshops

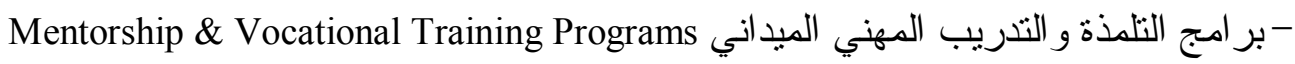
- بر امج التربية القيادية و المناظر ات. Leadership \& Debates Programs

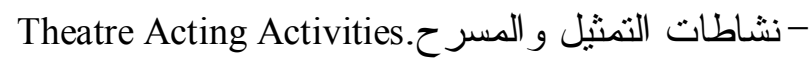
- ماعات مصادر التعلم و المشاغل المجزة لتسهيل وممارسة الهو ايات \& Workshops to Practice Hobbies. - المسابقات العلمية و الثقافية. Knowledge \& Science Competitions - المعارض الفنية و العلمية. Exhibitions Art \& Science Foreign Language Studies.در اسعة اللغات الأجنبية الفطية:

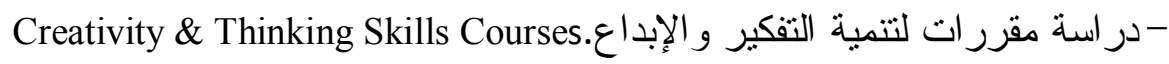
- بر امج التعليم عن طريق الحاسب. Computer Based Learning - المخيمات الصيفية. Summer Camps

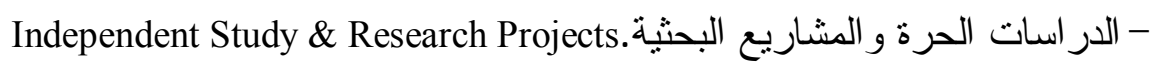

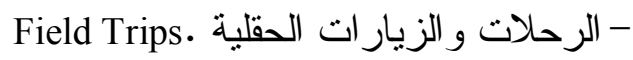

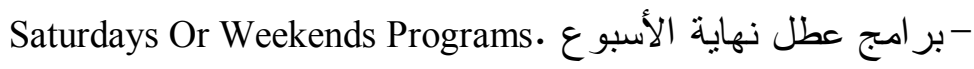

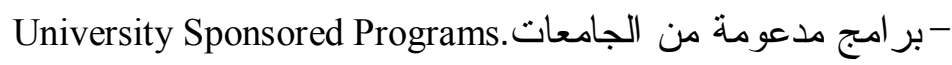
Future Problem Solving. برنامج حل المشكلات بطرق من إبداع الجية -

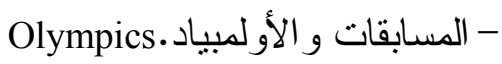
المحور الثاني عشر: الخطط الاراسية والمناهج:يرى المتخصصون في شؤون الإبداع أن الخطط الدراسية، و المناهج التربوية هي من

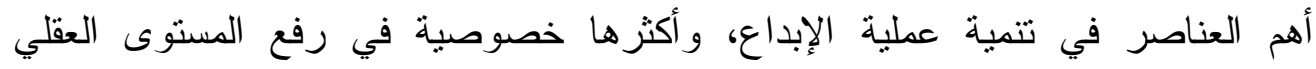
و التكاملي لدى الطلبة، وأي تقصير في هذا الجانب يمكن أن يعرقل تأهيل أجيال كاملة الأبدا ويحيل كل الأمة إلى كتلة من الجهل والتخلف. وإذا في راجعنا مدى الاهتمام الذي يلقاه 
المستوى الإبداعي في مؤسساتتا التربوية و التعليمية سيكون من السهل أن نلمس أنه متدني

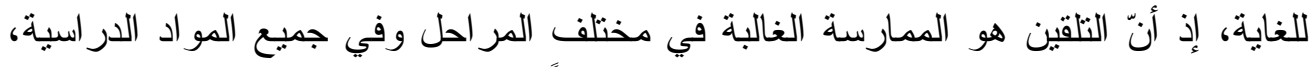

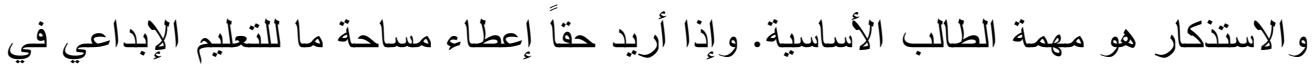

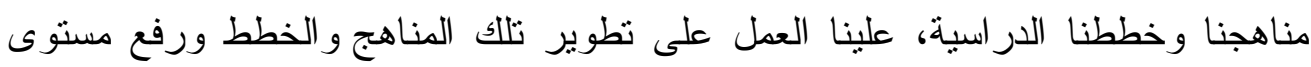

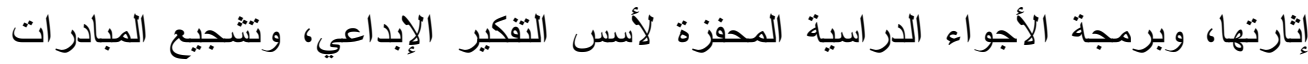

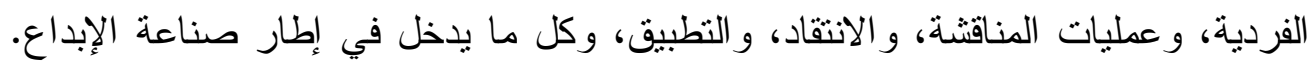

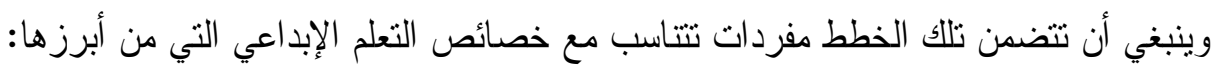

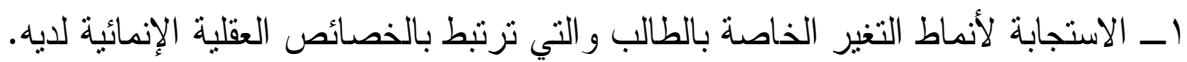

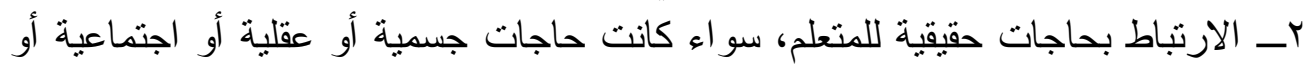
نفسية أو روحية.

rــ الاعتماد على الخبرة سو اء أكانت خبرة مباشرة حقيقية أم خبرة غير مباشرة. عــ قابلية الاستعمال في الحياة مما يجعله أكثر فاعلية و أكثر بقاءً. ○ـ إمكانية مناسبته لكل فرد وقدر اته و اتجاهاته الذاتية. T_ احتو ائه على معلومات ومهار ات و اتجاهات قابلة للبقاء. Vـ تحفيزه للطالب على التقكير الإبداعي و البحث عن الأسباب و العلاقات أكثر من البحث عن النتائج.

^ــ تحفيزه للطالب على تطوير مهار ات العمل المنتج و القيم الاجتماعية الأصيلة.

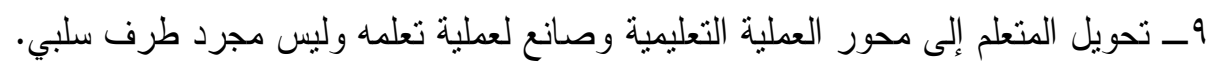

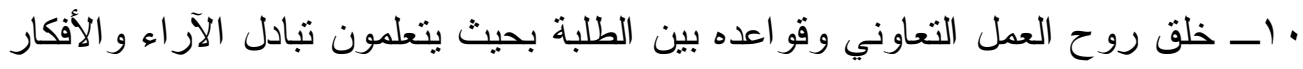

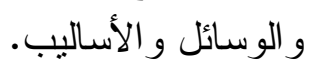

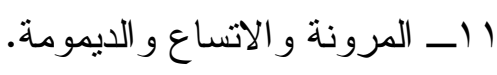
rا_ـ تحقيق النماء المتكامل للفرد جسمياً وعقلياً واجتماعياً.

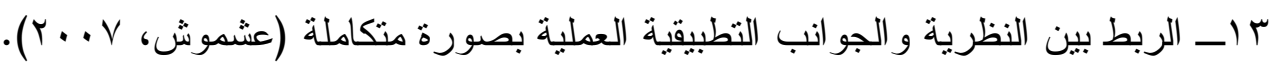

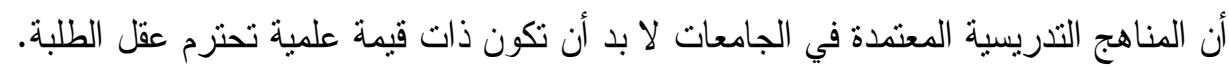

\section{المحور الثالث عشر : الاستقلال الأكاديمي والإداري والمالي:}

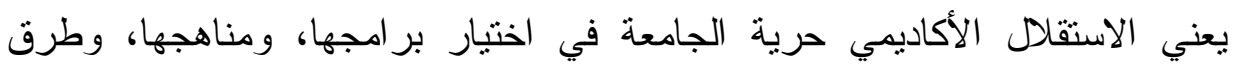

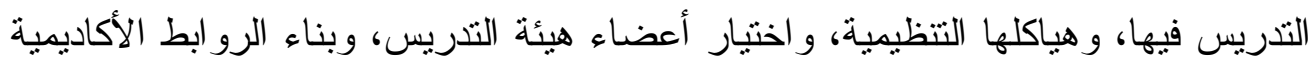

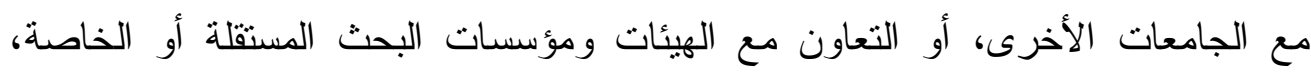

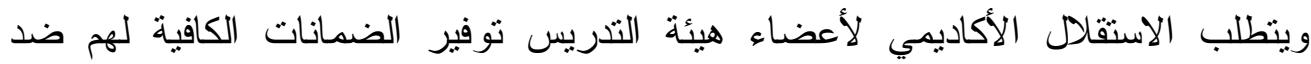

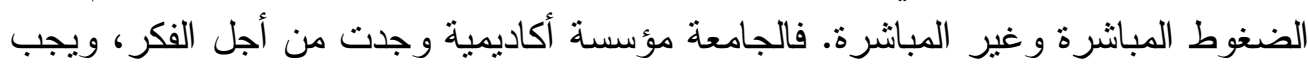
أن تلتزم بالحقيقة كل الحقبقة، وأن تتمي روح البحث و الابتكار و اكتشاف آفاق جديدة للمعرفة. 
ويعتبر الاستقلال الإداري من مستلزمات الاستقلال الأكاديمي. ويتضمن تشكيل

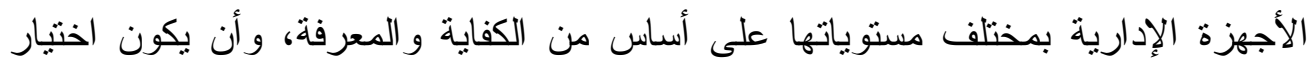

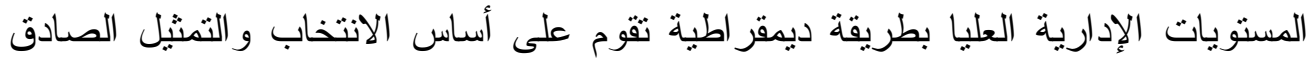

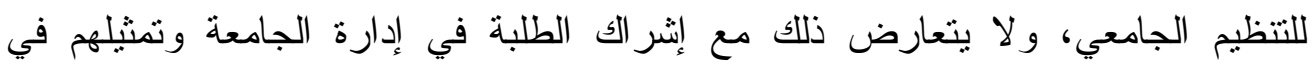

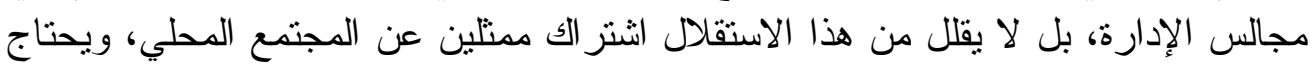

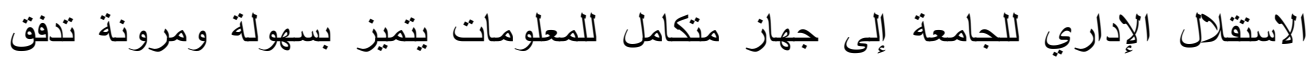

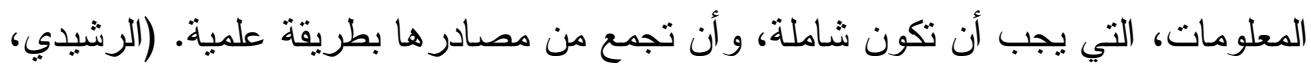

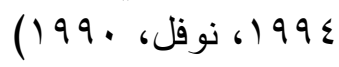

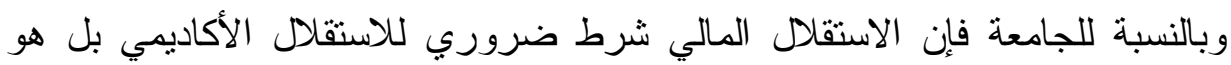

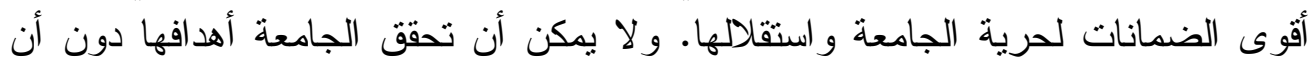

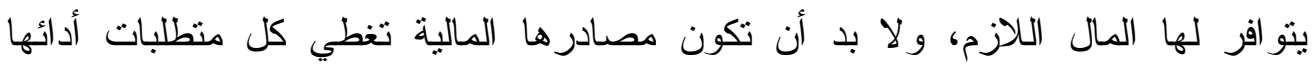

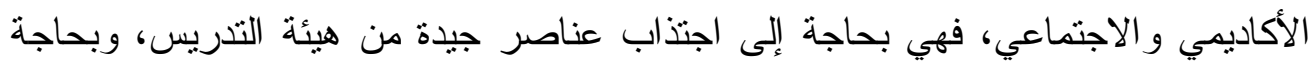

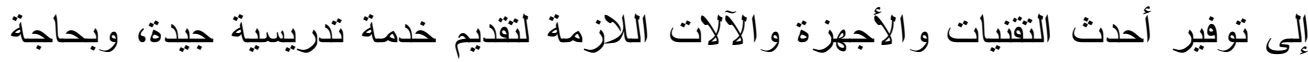

إلى توفير الميز انيات اللازمة لإجر اء البحوث، وتمويل بر امج خدمة المجتمع. (الرشيدي، ـو 199). المحور الثالث عشر: الحرية الأكاديمية:-

يقصد بها غياب القيود التي يمكن أن تفرض على الجامعة من قبل السلطات السياسية

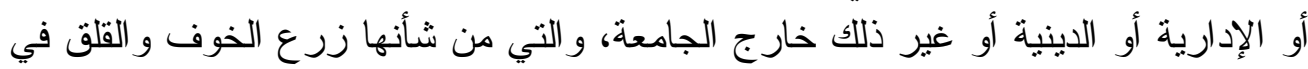

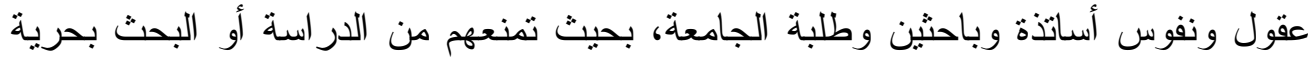

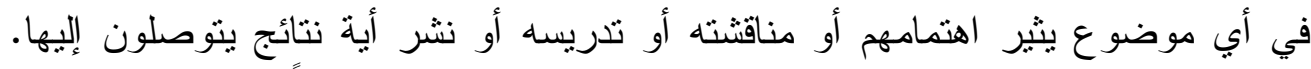

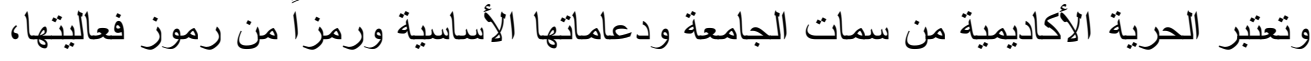

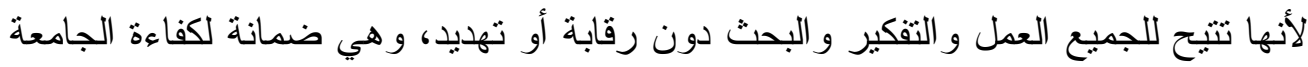

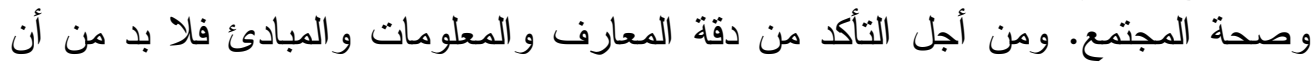

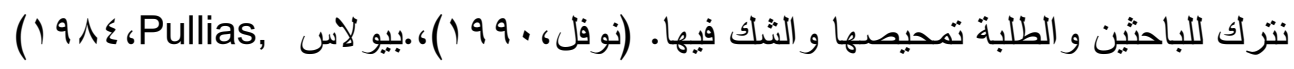

\section{الخلاصة و التوصيات}

تعنبر وظيفة الخدمة العامة فى التعليم العالي الأمريكي إحدى الوظائف الثالثة

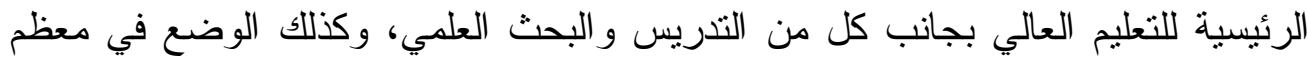

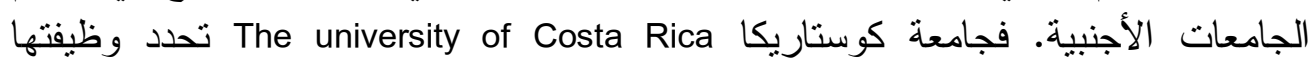

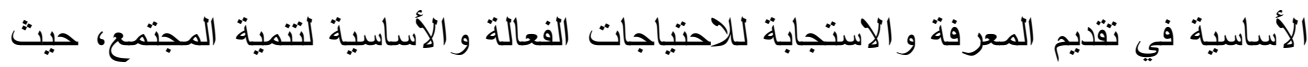

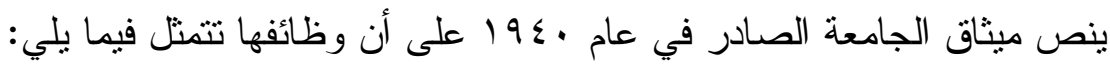

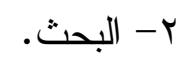

ع - تتمية القدر ات الإبداعية للطلبة.

1-التعليم.

ب - ب- الخدمة العامة. 
צ- التتمية المهنية و الروحية.

0- نشر المعرفة.

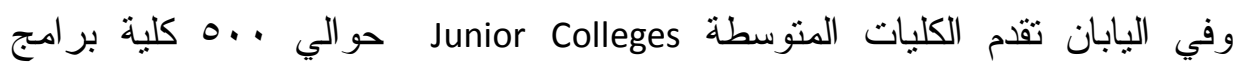

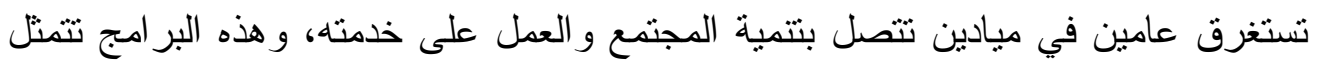

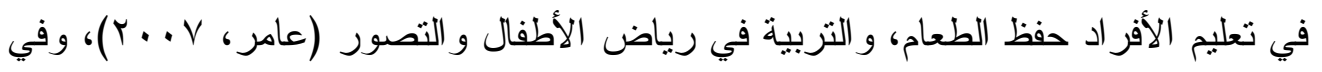
هذا الإطار نقتر ح ما يلي: ا . يجب تهيئة طلبة الثانوية العامة للار اسة الجامعية عن طريق المحاضرات العامة،

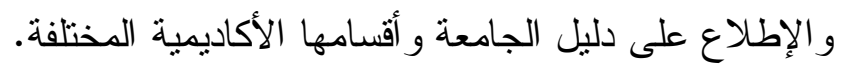

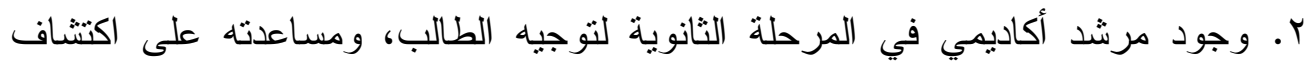
قدر اته، وحل مشاكله الأكاديمية.

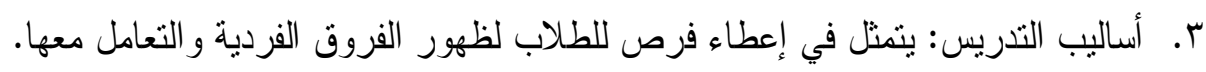

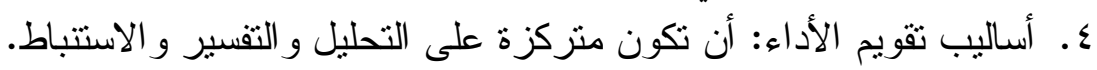

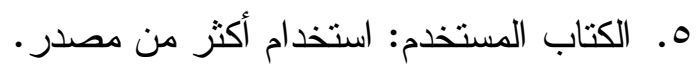

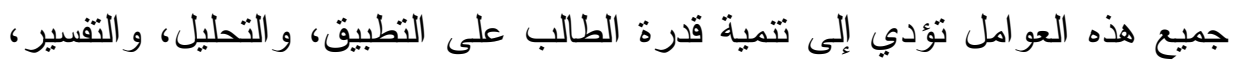

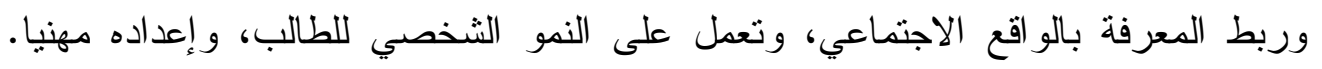

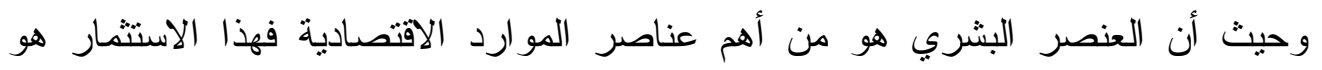

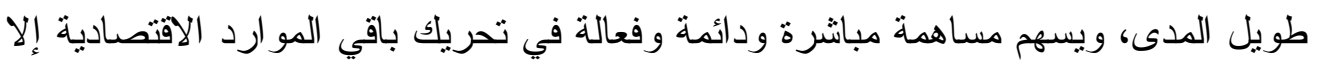

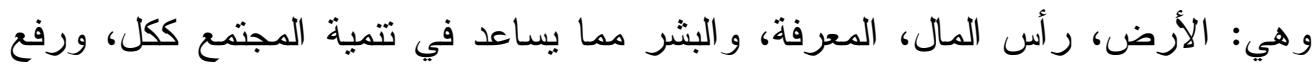
دعائم الوطن إلى أعلى المستويات.

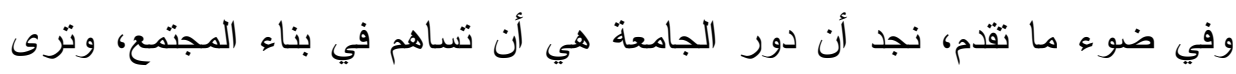

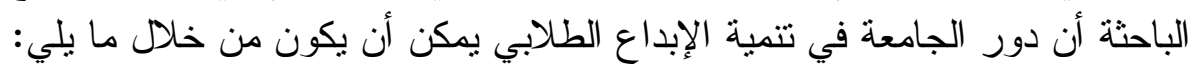
- تسهيل عملية التعلم الذاتي للطالب من خلال تمكينه من استخدام وسائل البحث الحيد الحديثة.

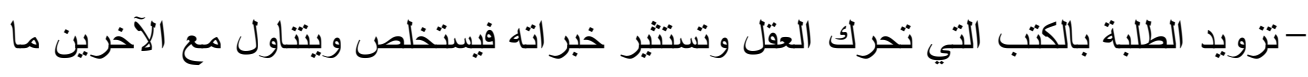

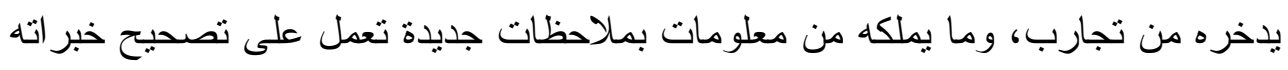

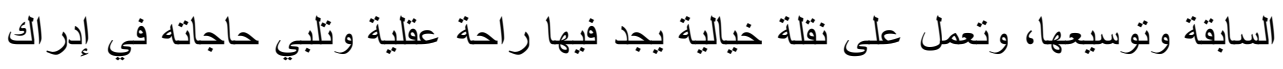
ما هو جديد.

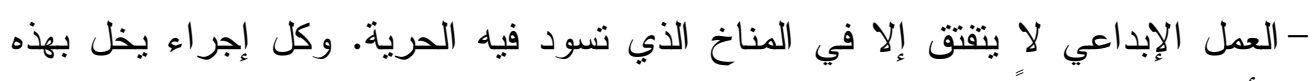

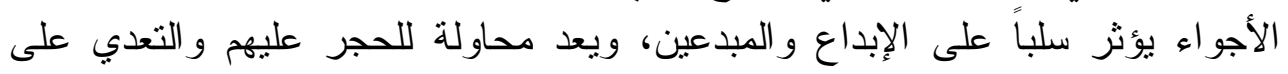
حقوقهم الأولية. - العمل على زرع التتافس البناء بين الطلبة. فكثير أ ما تكون إبداعات الآخر ونتاجاته عامل

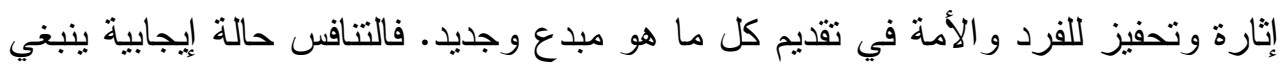

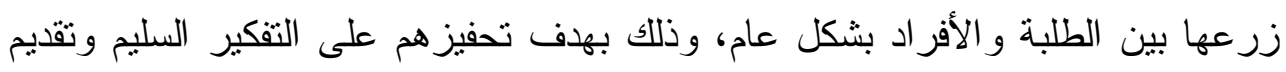

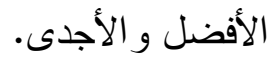


- أن نوفر الوسائل و التقنبات التزبوية الحديثة. - أن تفتح دور ات في أساليب التدريس الحديثة.

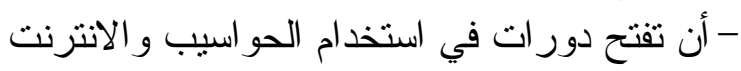

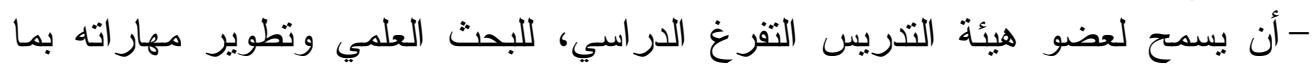
ينعكس إيجابيا على الطلبة. - أن يسمح لعضو هيئة التدريس المشاركة في المؤتمر ات خار ج الجامعة و الدولة، أن توفر

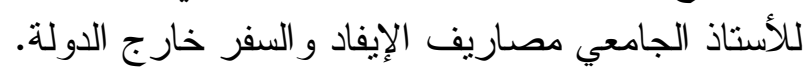

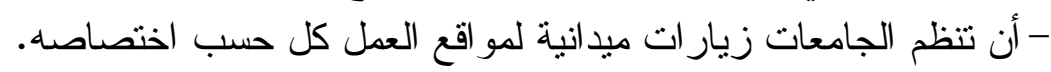

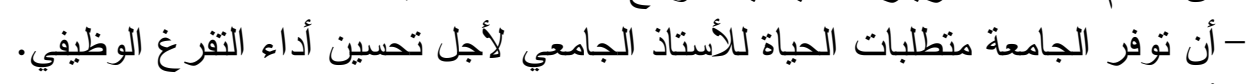

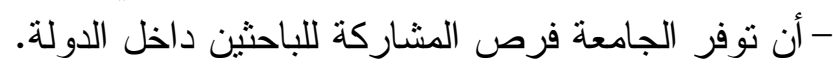

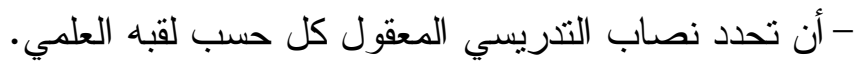

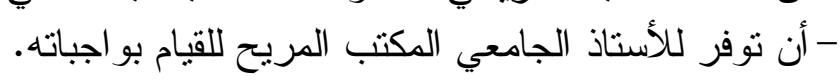

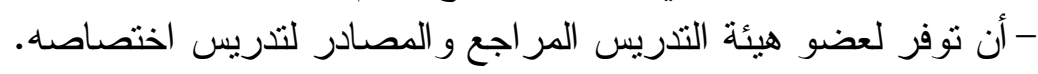

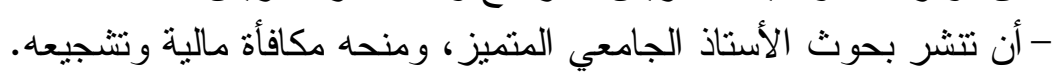

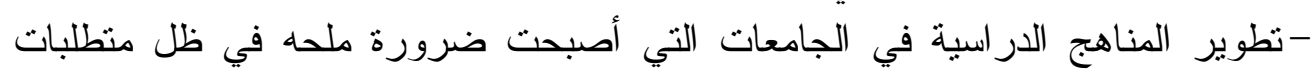
العصر (الانفجار ألمعلوماتي).

- تدريب وتطوير طلبة وأساتذة الجامعات في مجال الحاسوب والانير الانترنت، ومحو أمية

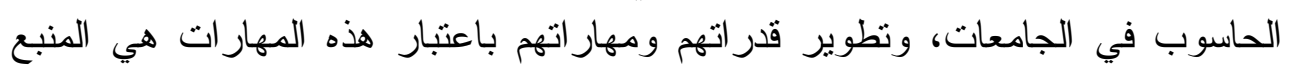

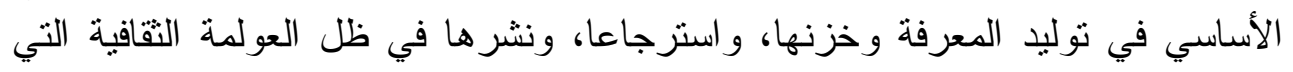

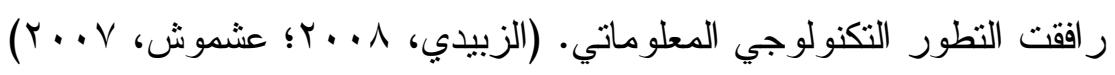

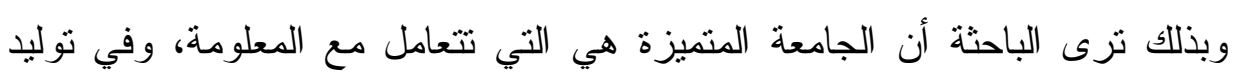

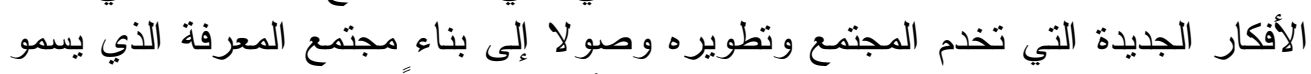

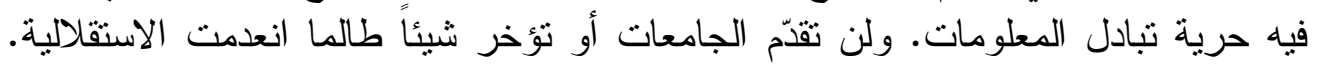

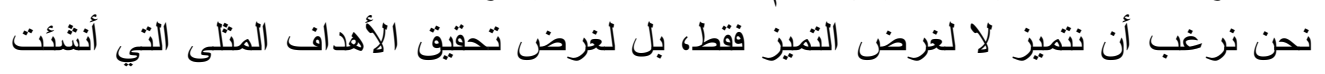

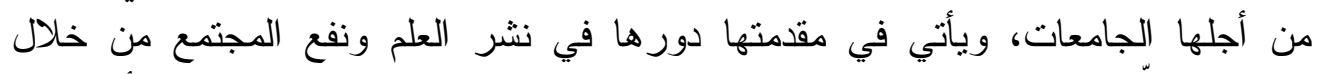

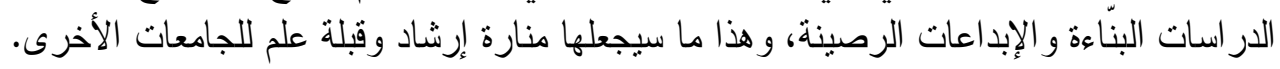

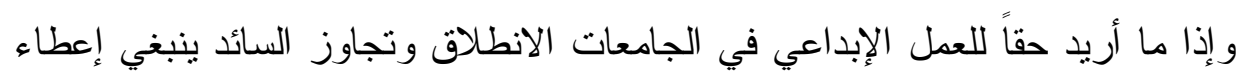

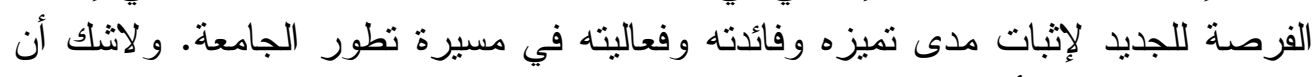

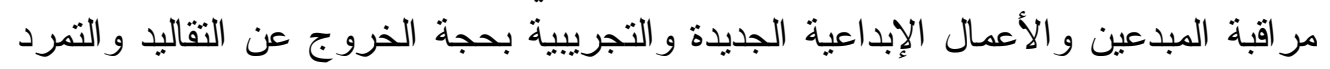

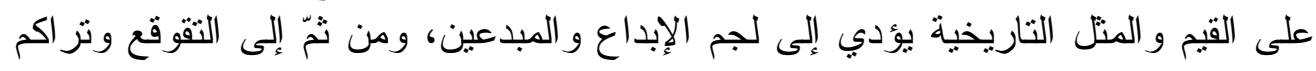
التخلف و الجمود. 


\section{المر اجع العربية والأجنبية:

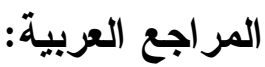

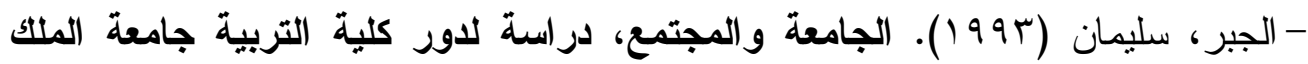

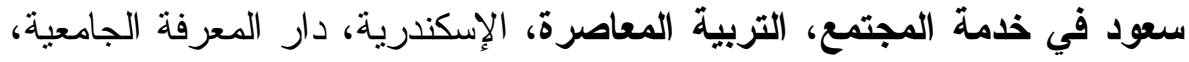

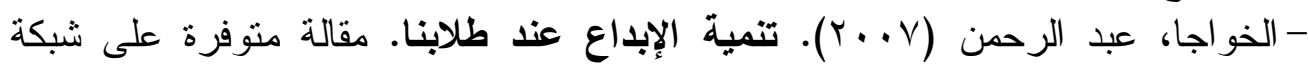

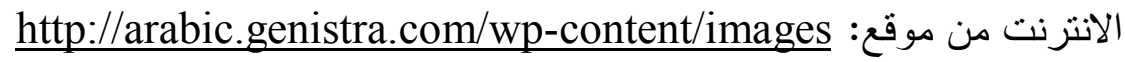
- الرشيدي، بشير (199 (1)). الكفاءة الداخلية لجامعة الكويت و التحديات المعاصرة، وقائع الكائع

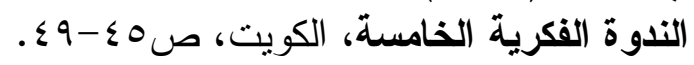

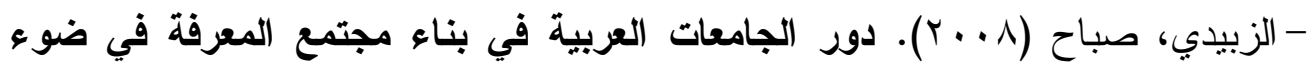

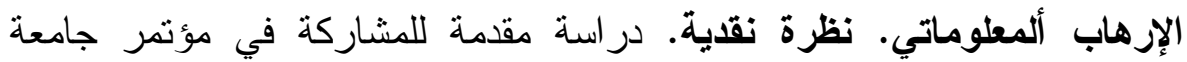

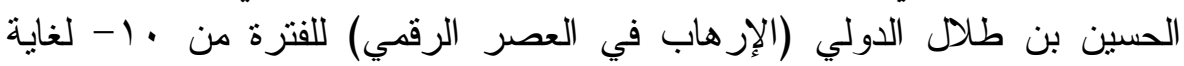

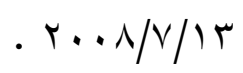

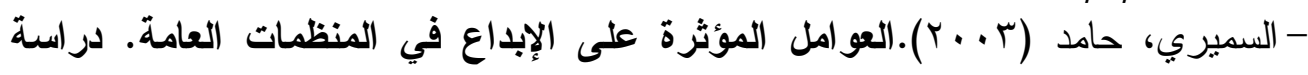

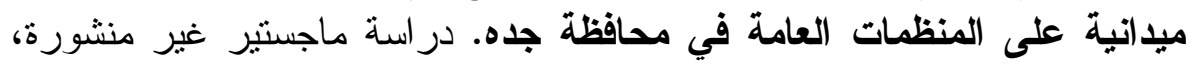
جامعة الملك عبد العزيز ، المملكة العربية السعودية.

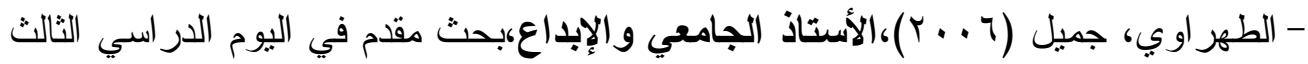

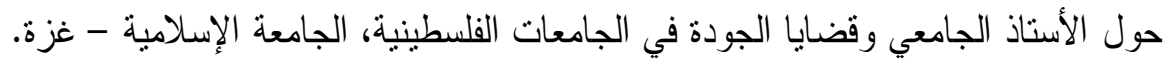

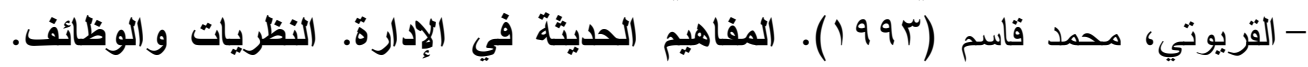

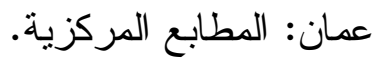

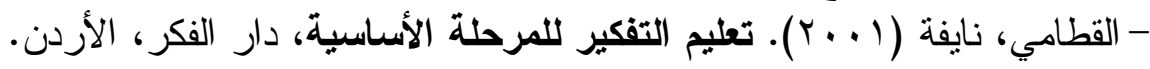

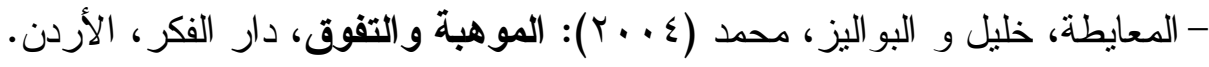

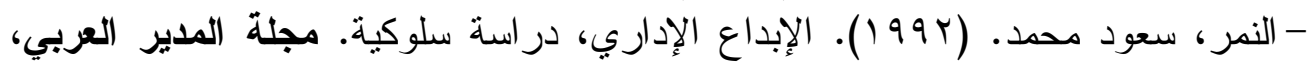

$$
\text { القاهرة، العدد }
$$

- جبر، احمد ( . . . ب). نشرة مضامين الدراسات التربوية حول الإبداع في فلسطين،

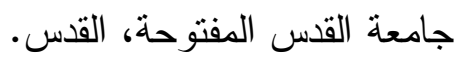

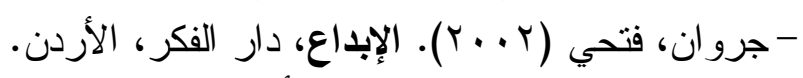

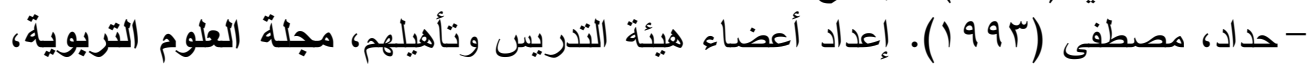

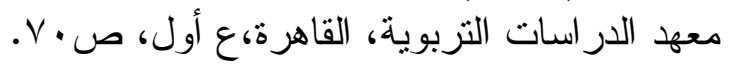

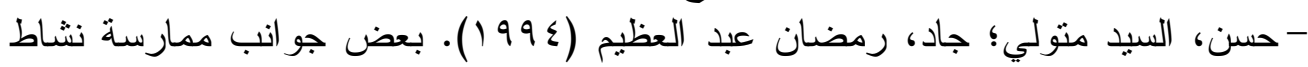

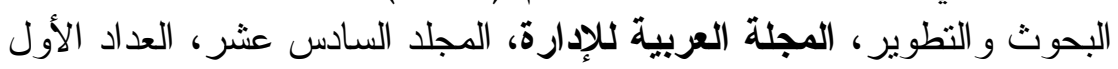

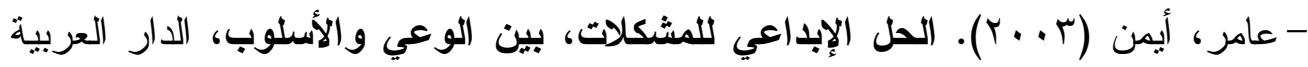

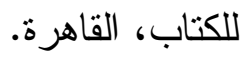




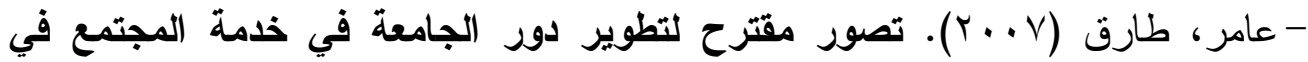

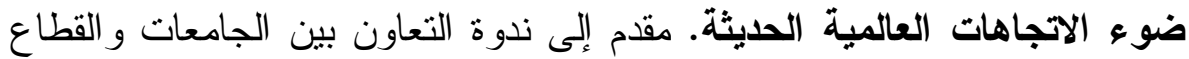

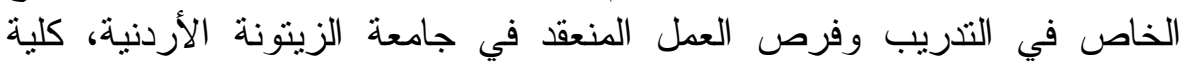

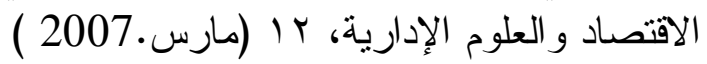

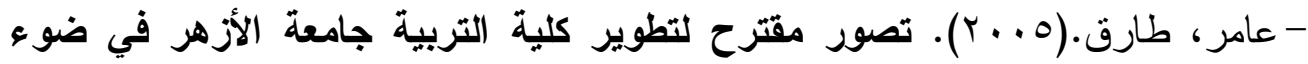

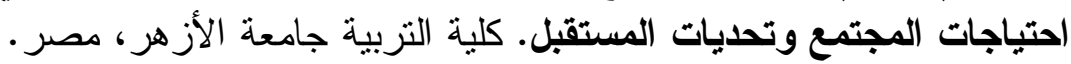

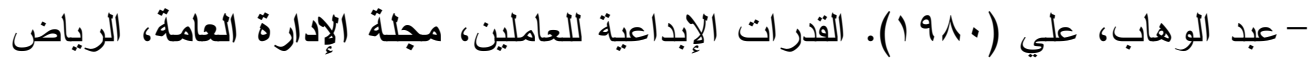

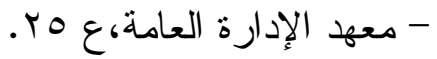

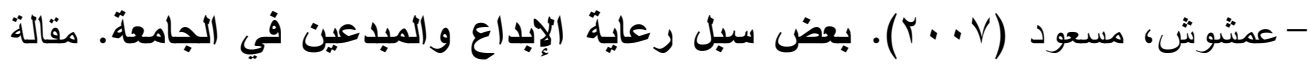

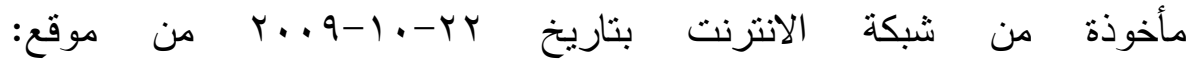
http://www.yemenitta.com/ararticles.htm

- عيسوي، عبد الرحمن (ع/91/). تطوير التعليم الجامعي العربي، دراسة ميدانية، دار النهضة

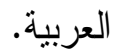

- قطامي،يوسف( • (99 ). تفكير الأطفال تطوره وطرق تعليمه، طا الأهلية للنشر و التوزيع، عمان.

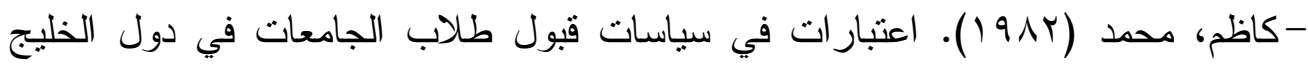

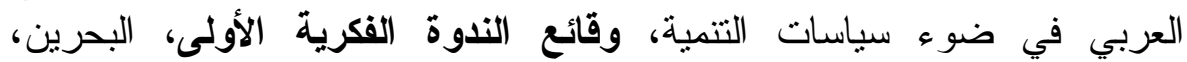

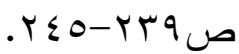

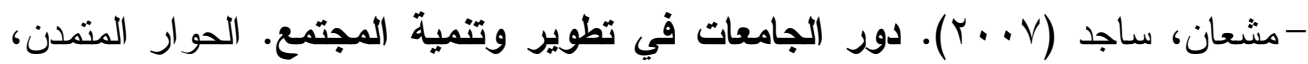

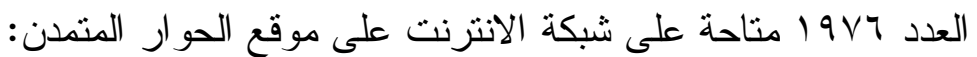

http://www.ahewar.org/debat/show.art.asp?aid=102726

- نوفل، محمد (.99 (19). تأملات في فلسفة التعليم الجامعي العربي، التربية الجايدة، العدد

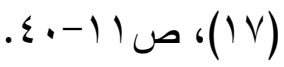

$$
\begin{aligned}
& \text { المراجع الأجنبية: }
\end{aligned}
$$

- Amabile, T.M. (1983). The social psychology of creativity. New York: Springer- Verlag Incorporated.

- Goldhare, Joel D..(1986) "In the factory of the future, Innovation is Productivity", Research Management, VOLXXIX, No 2.

- Jones, G.R.(1995). "Organizational Theory: Text and Cases", Addison- Wesley Com, USA.

- Loveless, A. L. (2002). Literature review in creativity, new technologies, and learning. Brighton: NESTA. www.nestafuturelab.org/research/reviews/cr01.htm

- Pisano. C.P. \& Wheelwright. S.C.(1995). "The New Logic Of HighTechs R\&D", HBR, Sep, Oct. 1995.

- Pullias, V. Earl (1984). Principles and Values For College and University Administration, New York.

- Schermerhom, J.R \& Hunt, J.G. \& Osbom, R.N.(1997). "Organizational Behavior", 6th ed, John Wiley \& Sons, USA. 